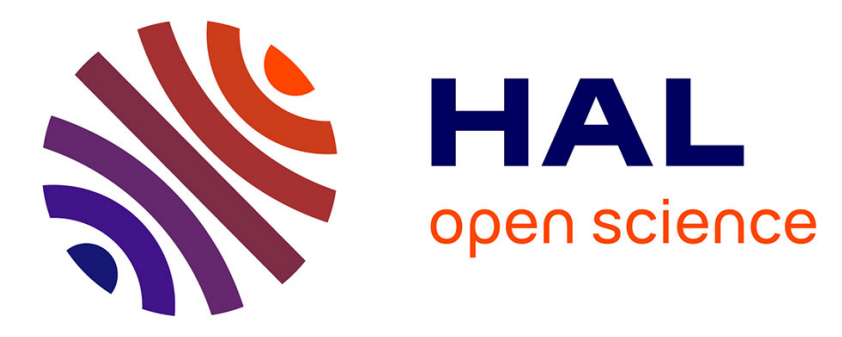

\title{
Polymethacrylic Acid Shows Thermoresponsivity in an Organic Solvent
}

Esther Cazares-Cortes, Benjamin C Baker, Kana Nishimori, Makoto Ouchi, François Tournilhac

\section{- To cite this version:}

Esther Cazares-Cortes, Benjamin C Baker, Kana Nishimori, Makoto Ouchi, François Tournilhac. Polymethacrylic Acid Shows Thermoresponsivity in an Organic Solvent. Macromolecules, 2019, 52 (15), pp.5995-6004. 10.1021/acs.macromol.9b00412 . hal-02351499

\section{HAL Id: hal-02351499 https://hal.science/hal-02351499}

Submitted on 6 Nov 2019

HAL is a multi-disciplinary open access archive for the deposit and dissemination of scientific research documents, whether they are published or not. The documents may come from teaching and research institutions in France or abroad, or from public or private research centers.
L'archive ouverte pluridisciplinaire HAL, est destinée au dépôt et à la diffusion de documents scientifiques de niveau recherche, publiés ou non, émanant des établissements d'enseignement et de recherche français ou étrangers, des laboratoires publics ou privés. 


\section{Polymethacrylic Acid Shows Thermoresponsivity in an Organic Solvent}

Esther Cazares-Cortes, ${ }^{\mathrm{a}}$ Benjamin C. Baker, ${ }^{\mathrm{a}} \dagger$ Kana Nishimori, ${ }^{\mathrm{b}}$ Makoto Ouchi, ${ }^{\mathrm{b}}$ and François Tournilhac. ${ }^{\mathrm{a} *}$

${ }^{a}$ Molecular, Macromolecular Chemistry, and Materials Laboratory, CNRS, ESPCI-Paris, PSL Research University, 10 rue Vauquelin 75005 Paris, France

${ }^{\mathrm{b}}$ Department of Polymer Chemistry, Graduate School of Engineering, Kyoto University, Katsura Nishikyo-ku, Kyoto 615-8150, Japan

KEYWORDS: Structure and phase transitions of polymers, thermoresponsive polymer solutions, chemistry of polymer materials, H-bonded polymers, IR spectroscopy.

\section{TOC}

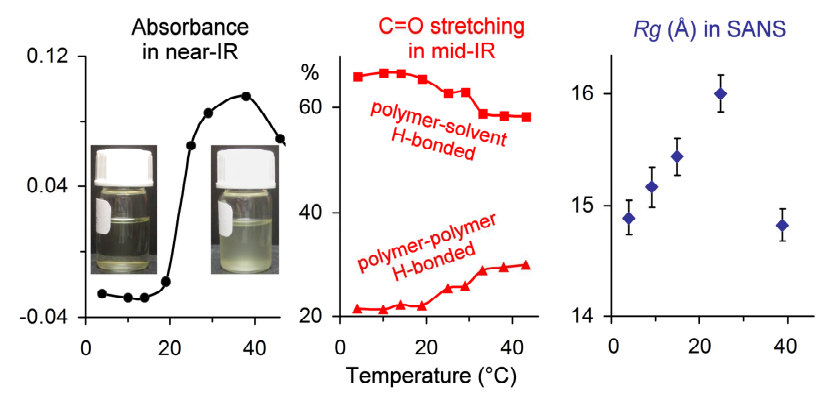


ABSTRACT: The alternating sequenced copolymer, poly-(methacrylic acid-alt-hydroxyethyl acrylate), p(MAA-alt-HEA) was recently found to display a lower critical solution temperature (LCST) behaviour in 1,2-dimethoxyethane (DME), whereas the random copolymer of same average molecular weight and composition did not. As an effort to understand this peculiar behaviour, we investigated solutions of both corresponding homopolymers, poly(methacrylic acid) (pMAA) and poly(2-hydroxyethyl acrylate) (pHEA) in DME. We found that in same temperature range and concentration, pHEA is fully soluble, whereas pMAA shows the LCST behavior just like the alternating copolymer. Based on Hansen's parameters of the homopolymers, it would be predicted that neither should dissolve in the DME. Solubility is therefore connected to specific solvent-polymer interactions and more specifically formation of polymer-solvent complex via hydrogen bonds. We designed a method which combines midinfrared (MIR) and near-infrared (NIR) spectroscopy in solution to study hydrogen bonding as a function of temperature (by MIR) with simultaneous monitoring of LCST (by NIR). In parallel, the global shape of polymer chains and aggregates was characterized by small angle neutrons scattering (SANS) in deuterated DME. It is found that pMAA chains form aggregates upon increase of temperature through formation of cyclic $\mathrm{H}$-bonded dicarboxylic dimers. As for pHEA, the solvent's quality of DME slightly decreases with temperature but aggregation is prevented by entropic repulsion of the flexible side chains. We thus concluded that nonoccurrence of LCST in the random copolymer is due to the presence of pHEA homoblocks that keep the copolymer constantly soluble in the whole temperature range. 


\section{INTRODUCTION}

Stimuli-responsive polymers are capable of modifying their chemical and/or physical properties upon exposure to different stimuli (temperature, $\mathrm{pH}$, ionic strength...). Synthetic smart polymers and networks are considered for practical use; in particular for on-demand drug delivery, tissue generation/repair and molecular recognition. ${ }^{1,2}$ In this area, acrylic polymers take a prominent place for they offer a robust non-hydrolyzable carbonated main-chain together with virtually any type of side chain functionality. Moreover acrylic and methacrylic monomers have been successfully applied in both classic (uncontrolled), living, and more recently sequence-controlled polymerizations techniques. ${ }^{3,4,5}$

Acrylic and methacrylic systems, that show conformational changes in water, in response to above mentioned stimuli are numerous. Thus, aqueous solutions of polymethacrylic acid (pMAA) behave as highly soluble polyelectrolytes at high or neutral $\mathrm{pH}$ but show a lower critical solution temperature (LCST) behavior at low $\mathrm{pH}^{6}$ And to give a single example of application, pMAA-based hydrogels may be used to protect hydrolysable drugs from acidic media and are reported among the most suitable synthetic polymers for oral insulin delivery. ${ }^{7,8}$

Stimuli responsive systems, able to work in an organic solvent are less common but might be useful, for instance to design smart reaction media for organic synthesis. Early observations relate to phase separations occurring close to the critical point (i.e. above the boiling point) of the solvent. ${ }^{9}$ A notable exception, already mentioned by Flory in 1954 is polyacrylic acid (pAA) which was reported to show an LCST well below the boiling point of dioxane. ${ }^{10-12}$ There are some other systems ${ }^{12}$ but the list is by far not comparable to what exists in water and more importantly, there is up to the present no general strategy towards the discovery of new solventpolymer LCST systems.

In this respect, the recently synthesized alternating copolymer poly-(methacrylic acid-althydroxyethyl acrylate), ${ }^{13}$ p(MAA-alt-HEA) caught our attention. This copolymer is alternated whilst solely composed of polar acrylic monomers. In 1,2-dimethoxyethane (DME) a solution of p(MAA-alt-HEA) with $M_{n}=4400$ g.mol ${ }^{-1}$ was reported to show a lower critical solution temperature (LCST) behavior in the $25-40^{\circ} \mathrm{C}$ range, whereas the random copolymer of same average composition was scarcely soluble throughout the temperature range. ${ }^{13}$ The alternating 
sequence of two functional acrylic monomers thus provides particular polymer-solvent and polymer-polymer interactions, compared to random.

Classically, to approach the solubility phenomena in organic solvents, the analysis based on tridimensional Hansen parameters is used. Based on the values of these parameters, neither pMAA nor pHEA nor any of their copolymers should be soluble in DME which already at this stage is contradicted by the facts. Hansen's approach certainly takes into account the effect of polar groups and hydrogen bonds, but treats the presence of solvent molecules as a mean field. This view of things gives no way to explain the observed phase separation, nor the difference in behavior between statistic and alternating copolymers. Clearly these are specific interactions by hydrogen bonds that are responsible of the phenomena observed.

The difficulty in understanding the LCST in a system like this is therefore to simultaneously study the state of association by hydrogen bonds and the aggregation phenomena, that eventually lead to phase separation. To this end, a special infrared spectroscopy protocol was hereby designed: mid-infrared spectroscopy (MIR) is used to evaluate the H-bonding state throughout phase separation whilst simultaneous detection of LCST is achieved through monitoring the change of turbidity in the near-infrared (NIR) range. DME is sufficiently transparent in both IR regions to allow meaningful analysis. In parallel, the global shape of polymer chains and aggregates was characterized by small angle neutron scattering (SANS), a technique fully adapted to polymer solutions, especially when radiation sensitive compounds and low-molar mass materials are considered.

We investigated the solution behavior of low molar mass homopolymers, pMAA and pHEA. We found that pHEA is fully soluble in DME, whereas pMAA shows an LCST behavior in the same temperature range and solvent as the alternating copolymer p(MAA-alt-HEA). To our knowledge, the LCST of pMAA in DME was previously unreported in the literature. IR analysis shows that this is related to the cleavage of solvent-polymer H-bonds and simultaneous appearance of polymer-polymer linkages through $\mathrm{H}$-bonded dicarboxylic dimers, conducive to aggregation. In pHEA the solvent's quality of DME slightly degrades with temperature but aggregation does not take place, probably due to entropic repulsion of flexible side chains. We conclude that it is the absence of homo-pHEA blocks that is responsible for the LCST in the alternating copolymer. 


\section{EXPERIMENTAL SECTION}

Materials — Deuterated 1,2 dimethoxyethane (DME- $d_{10}, 98 \%$ ) was supplied by Eurisotop, 1,2 dimethoxyethane (DME, 99.5\% inhibitor free) was purchased from Sigma-Aldrich and conditioned under argon after each sampling. Dimethyl formamide (DMF, 99.8\%), 1-4,dioxane (99.5\%), 2-hydroxyethyl acrylate (HEA, 98\%), tert-butyl methacrylate (tBuMA, 98\%), cumyl dithiobenzoate (CDB, 99\%), n-butyl acrylate (99\%), tributyl phosphine (97\%) were supplied by Sigma-Aldrich. S-(2-cyano-2-propyl)-S-dodecyl trithiocarbonate (CPDT, 97\%) was supplied by ABCR, 2,2'-azobis (2-methylpropionitrile) (AIBN, 98\%) was supplied by Acros, n-butylamine (99\%) was supplied by Alfa Aesar. $\mathrm{RuCp}{ }^{*} \mathrm{Cl}\left(\mathrm{PPh}_{3}\right)_{2}$ (Aldrich) and $n$-Dibutylamine (TCI, purity $>99 \%$ ) were used without purification. Ehyl-2-chloro-2-phenylacetate (ECPA; Aldrich, purity > 97\%) was distilled before use. 1,2,3,4-Tetrahydronaphthalene (tetralin, Kishida Chemical; purity $>98 \%$ ), an internal standard in ${ }^{1} \mathrm{H}$ NMR, was dried over calcium chloride overnight and distilled twice over calcium hydride. Toluene (Wako, purity > 99\%) was dried over molecular sieves $3 \mathrm{~A}$ and bubbled with dry nitrogen for $30 \mathrm{~min}$ before use. Poly(methacrylic acid) with a mol. weight of $100000 \mathrm{~g} / \mathrm{mol}$ was purchased from Polyscience, Inc.

Analytical methods — Bulk Fourier-Transform Infrared (FT-IR) spectra were recorded at 25 and $50{ }^{\circ} \mathrm{C}$ in the $400-4000 \mathrm{~cm}^{-1}$ wavenumber region $\left(4 \mathrm{~cm}^{-1}\right.$ resolution) using a Bruker Tensor 37 spectrometer by casting polymer solutions on the top of a Specac Golden Gate ATR accessory. ${ }^{1} \mathrm{H}$ NMR spectra were recorded from DMSO- $d_{6}$ solutions using a Bruker Avance 400 spectrometer $(400 \mathrm{MHz})$. Molar masses and polymolecularity indexes of tBuMA and pHEA were determined by Size-Exclusion Chromatography (SEC), using a Malvern GPC1000 pump, Viscotek TDA 305 triple detection array and three thermostatically controlled columns (LT5000L). Tetrahydrofuran (THF) was used as eluent at $35{ }^{\circ} \mathrm{C}$, at a flow rate of $1 \mathrm{~mL} \cdot \mathrm{min}^{-1}$. The molar masses $\left(M_{n}\right.$ and $\left.M_{w}\right)$ and polymolecularity index $\left(M_{w} / M_{n}\right)$ were obtained using the refractive index (RI) signal with poly(methyl methacrylate) conventional calibration. Molar masses and polymolecularity index of pMAA were determined by aqueous SEC, using an Omnisec triple detection array (refractive index, RALS-LALS detector, viscosimeter) and three thermostatically controlled columns (A3000, A6000M, A7000). Aqueous $\mathrm{NaNO}_{3}$ solution at 0.2 $\mathrm{M}\left(\mathrm{NaN}_{3} 200 \mathrm{ppm}\right)$ was used as eluent at $25{ }^{\circ} \mathrm{C}$, at a flow of $0.8 \mathrm{~mL} \cdot \mathrm{min}^{-1}$. The apparent 
molecular weights $\left(M_{n}\right.$ and $\left.M_{w}\right)$ and polymolecularity index $\left(M_{w} / M_{n}\right)$ were measured using poly(ethylene oxide) conventional calibration $\left(M_{n}=24000 \mathrm{~g} \cdot \mathrm{mol}^{-1}\right)$.

Synthesis of poly methylacryclic acid (pMAA) $(D P=18)$ - Purification of the monomer tBuMA was achieved via passing the neat liquid through a basic activated alumina column $(\mathrm{d}=2$ $\mathrm{cm}, 1=10 \mathrm{~cm}$ ) under pressure (300 mbar). After filtration on paper to remove residual alumina, the purified monomer was deoxygenated by bubbling $\mathrm{N}_{2}$ for 1 hour. In a schlenk tube the RAFT agent cumyl dithiobenzoate (CDB, $454 \mathrm{mg}, 1.67 \mathrm{mmol})$ and DMF $(5 \mathrm{~mL})$ were put to form a purple solution and then deoxygenated with $\mathrm{N}_{2}$ for 1 hour. In parallel, a stock solution of 2,2'azobis(2-methylpropionitrile) (AIBN, $2.73 \mathrm{mg} / \mathrm{mL}$ in DMF) was prepared. The monomer (4.55 $\mathrm{g}, 32.0 \mathrm{mmol})$ and $100 \mu \mathrm{L}(0.17 \mathrm{mmol})$ of the AIBN stock solution were added to the schlenk tube sequentially and the tube placed in an oil bath at $65{ }^{\circ} \mathrm{C}$ for 24 hours and stirred under $\mathrm{N}_{2}$. Aliquots $(0.1 \mathrm{~mL})$ were collected at both 0 hours and 24 hours for analysis with SEC, ${ }^{1} \mathrm{H}$ NMR and IR. After 24 hours the temperature was reduced to $40{ }^{\circ} \mathrm{C}$ and n-butyl amine $(2.48 \mathrm{~g})$ was added under $\mathrm{N}_{2}$. The solution was allowed to react under $\mathrm{N}_{2}, 40{ }^{\circ} \mathrm{C}$ for a further 72 hours before a color change from a purple to a yellow solution was completed. After color change, butyl acrylate $(435 \mathrm{mg})$ was added; tributyl phosphine $(0.1 \mathrm{~mL})$ and the solution were allowed to react at $30{ }^{\circ} \mathrm{C}$ under $\mathrm{N}_{2}$ for a further 24 hours. The $\mathrm{p}(\mathrm{tBuMA})$ was obtained via precipitation into iced water $(50 \mathrm{~mL})$ and methanol $(100 \mathrm{~mL})$, the precipitate isolated via filtration and dried under vacuum and $\mathrm{P}_{2} \mathrm{O}_{5}$ (24 hours). The resultant $\mathrm{p}(\mathrm{tBuMA})$ was subjected to SEC analysis. $M_{n}$ (SEC, $\mathrm{THF})=3661 \mathrm{~g} \cdot \mathrm{mol}^{-1} ; M_{w} / M_{n}(\mathrm{SEC}, \mathrm{THF})=1.21$.

For hydrolysis the p(tBuMA) (52 g, $14 \mathrm{mmol}$ ) was dissolved in dioxane (100 mL) and $12.6 \mathrm{~mL}$ of $\mathrm{HCl}_{\mathrm{aq}}(140 \mathrm{mmol})$ added dropwise before heating to $85{ }^{\circ} \mathrm{C}$ for 12 hours. After cooling, the solvent was part removed under vacuum and the product precipitated and isolated via filtration, then washed with ether and dried under vacuum. The resultant pMAA was subjected to FT-IR, SEC and ${ }^{1} \mathrm{H}$ NMR analyses (spectra in Supporting Information). The FT-IR spectrum $\left(50{ }^{\circ} \mathrm{C}\right.$ in bulk) was consistent with published data of pMAA $^{14 \mathrm{bis}}$ and assigned as follows: $v=3500-2500$ $\mathrm{cm}^{-1}$ (COO-H stretching, H-bonded), 2990-2941 cm $\mathrm{cm}^{-1}\left(\mathrm{CH}_{3}\right.$ and $\mathrm{CH}_{2}$ stretching modes), 1693 $\mathrm{cm}^{-1}$ ( $\mathrm{C}=\mathrm{O}$ stretching, H-bonded), $1480 \mathrm{~cm}^{-1}\left(\mathrm{CH}_{3}\right.$ and $\mathrm{CH}_{2}$ deformations $), 1448 \mathrm{~cm}^{-1}(\mathrm{O}-\mathrm{H}$ deformation), $1388 \mathrm{~cm}^{-1}$ ( $\mathrm{CH}_{3}$ deformation), $1262 \mathrm{~cm}^{-1}$ (C-O stretching). ${ }^{14} M_{n}\left(\mathrm{SEC}, \mathrm{H}_{2} \mathrm{O}\right)=$ 5593 g.mol ${ }^{-1} ; M_{w} / M_{n}\left(\mathrm{SEC}, \mathrm{H}_{2} \mathrm{O}\right)=1.05 . M_{n}(\mathrm{NMR})=1710-2060 \mathrm{~g} \cdot \mathrm{mol}^{-1} .{ }^{1} \mathrm{H}$ NMR $(400 \mathrm{MHz}$, 
DMSO- $\left.d_{6}\right) \delta 12.33(\mathrm{~s},-\mathrm{COOH}), 7.48-7.13(\mathrm{~m}, \mathrm{Ar}-\mathrm{H}), 3.67-3.50\left(\mathrm{~m},-\mathrm{O}-\mathrm{CH}_{2}-\right), 2.77-2.67(\mathrm{~m},-$ $\left.\mathrm{S}-\mathrm{CH}_{2}-\mathrm{CH}_{2}-\mathrm{COO}-\right)$, $1.95-1.29$ (m, $\left.\left(-\mathrm{CH}_{2}-\mathrm{C}-\right) \mathrm{n}\right), 1.29-0.93\left(\mathrm{~m},\left(-\mathrm{C}-\mathrm{CH}_{3}\right) \mathrm{n} ;-\mathrm{C}-\left(\mathrm{CH}_{3}\right)_{2}\right)$, $0.44\left(\mathrm{~s},-\mathrm{CH}_{3}\right)$. Traces of diethylene glycol are present: $\delta 4.63(\mathrm{~s},-\mathrm{OH}), 3.67-3.50\left(\mathrm{~m},-\mathrm{CH}_{2}-\right.$ $\left.\mathrm{CH}_{2}-\mathrm{O}-\right)$.

Synthesis of poly methacrylic acid (pMAA) $(D P=59$ and 105) - To a Schlenk tube A, $\mathrm{RuCp}^{*} \mathrm{Cl}\left(\mathrm{PPh}_{3}\right)_{2}(47.8 \mathrm{mg}, 0.06 \mathrm{mmol})$, tBuMA $(9.75 \mathrm{~mL}, 60 \mathrm{mmol})$, ECPA (2.07 mL of 289 $\mathrm{mM}$ in toluene, $0.6 \mathrm{mmol}), n$-dibutylamine $(1.5 \mathrm{~mL}$ of $400 \mathrm{mM}$ in toluene, $0.6 \mathrm{mmol})$, tetralin $(0.3 \mathrm{~mL})$ and toluene $(1.4 \mathrm{~mL})$ were added at room temperature under dry argon; the total volume was $15 \mathrm{~mL}$. After mixing, $5 \mathrm{~mL}$ of the solution was injected in Schlenk tube B under dry argon and the two Schlenk tubes were placed in oil bath kept at $80{ }^{\circ} \mathrm{C}$. After each $5.5 \mathrm{~h}$ and 24.5 $\mathrm{h}$, Schlenk tube A and tube B were cooled to $-78{ }^{\circ} \mathrm{C}$ in dry ice-methanol to terminate the polymerization. Monomer conversions were determined by ${ }^{1} \mathrm{H}$ NMR from the integrated peak area of the olefinic protons of the monomer with tetralin as an internal standard (Conv. $=47 \%$ after $5.5 \mathrm{~h}, 89 \%$ after $24.5 \mathrm{~h}$ ). The polymers were purified with preparative SEC (tube A: $M_{\mathrm{n}}=$ $8100 \mathrm{~g} / \mathrm{mol}, M_{\mathrm{w}} / M_{\mathrm{n}}=1.08$, tube B: $M_{\mathrm{n}}=14400 \mathrm{~g} / \mathrm{mol}, M_{\mathrm{w}} / M_{\mathrm{n}}=1.11$ by SEC after purification). $D P$ s of the polymers after purification were determined from the signal intensity ratio of the ester protons (from ECPA) to aliphatic protons (0.8-2.5 ppm, from tBuMA) by ${ }^{1} \mathrm{H}$ NMR: $D P=55$ (tube A) and 103 (tube B).

For hydrolysis the p(tBuMA) (2.4 g, 16.9 mmol of tBuMA units) was dissolved in THF ( $80 \mathrm{~mL})$ and $17 \mathrm{~mL}$ of $\mathrm{HCl}$ aq. $(190 \mathrm{mmol})$ added dropwise before heating to $70{ }^{\circ} \mathrm{C}$ for 20 hours. After cooling, the solvent was part removed under vacuum and the solution was added dropwise in ether $(800 \mathrm{~mL})$. The precipitated polymer was isolated via filtration, then washed with ether and dialyzed in methanol using membrane (Spectra/Por®7, MWCO 1kD) for 1 days . The solution was evaporated and dried under vacuum. The resultant pMAA was subjected to FT-IR, SEC and ${ }^{1}$ H NMR analyses (spectra in Supporting Information).

Synthesis of Poly hydroxyl ethyl acrylate (pHEA) - pHEA is also obtained by RAFT polymerization. The monomer, 2-hydroxyethyl acrylate (30 g, $288.1 \mathrm{mmol})$, was dissolved in water $(100 \mathrm{~mL})$ with hydroquinone $(20 \mathrm{mg}, 0.18 \mathrm{mmol})$. Purification was achieved by extraction with heptane $(4 \times 30 \mathrm{~mL})$. The aqueous phase was then salted $(5 \mathrm{~g})$ and the monomer extracted into diethyl ether $(4 \times 30 \mathrm{~mL})$ to which hydroquinone $(30 \mathrm{mg}, 0.27 \mathrm{mmol})$ was added. The 
etherous phase was dried over $\mathrm{MgSO}_{4}(10 \mathrm{~g})$ and filtered before the purified monomer was isolated in vacuo $(9.23 \mathrm{~g})$. The purified monomer $(4.37 \mathrm{~g}, 39.88 \mathrm{mmol})$ and the RAFT agent, 2cyano-2-propyl dodecyl trithiocarbonate (CPDT, $0.57 \mathrm{~g}, 1.67 \mathrm{mmol}$ ) were added to DMF (15 $\mathrm{mL})$ under inert conditions. To this, the initiator AIBN (27.37 mg, $0.167 \mathrm{mmol})$ was added and the polymerization undertaken at $60^{\circ} \mathrm{C}, 2$ hours. The polymer solution was reduced in vacuo and dried at $100^{\circ} \mathrm{C}, 2$ hours to give pHEA $(4.807 \mathrm{~g})$. The sample was obtained as a water-soluble (c > $10 \mathrm{mg} / \mathrm{mL}$ ) viscous liquid. Additional purification was achieved by lyophilization of a $25 \mathrm{wt} \%$ solution in dioxane to remove DMF traces. The resultant pHEA was subjected to FT-IR, SEC and ${ }^{1} \mathrm{H}$ NMR analyses (spectra in Supplementary Information). The FT-IR spectrum $\left(25^{\circ} \mathrm{C}\right.$ in bulk) was consistent with published data of pHEA $^{15}$ and assigned as follows: $v=3600-3100 \mathrm{~cm}^{-}$ ${ }^{1}$ (O-H stretching) 2924-2853 cm $\mathrm{cm}^{-1}$ ( $\mathrm{CH}_{2}$ stretching modes), $1724 \mathrm{~cm}^{-1}$ (C=O stretching), 1448 $\mathrm{cm}^{-1}$ ( $\mathrm{CH}_{2}$ deformation), $1393 \mathrm{~cm}^{-1}$ (O-H bending), 1247-1159 $\mathrm{cm}^{-1}$ (C-O stretching of ester group), 1072 (C-O stretching of primary alcohol). ${ }^{14} M_{n}(\mathrm{SEC}, \mathrm{THF})=3100 \mathrm{~g} \cdot \mathrm{mol}^{-1} ; M_{w} / M_{n}$ $(\mathrm{SEC}, \mathrm{THF})=1.08 . M_{n}(\mathrm{NMR})=2420 \mathrm{~g} \cdot \mathrm{mol}^{-1} .{ }^{1} \mathrm{H}$ NMR $\left(400 \mathrm{MHz}, \mathrm{DMSO}-d_{6}\right) \delta 4.75(\mathrm{~m},-$ $\mathrm{OH}), 4.01\left(\mathrm{~m},-\mathrm{O}-\mathrm{CH}_{2}-\right), 3.57\left(\mathrm{~m},-\mathrm{CH}_{2}-\mathrm{OH}\right), 3.38-3.33\left(\mathrm{~m},-\mathrm{S}-\mathrm{CH}_{2}-\right)$, 2.26-1.46 (m, $\left(-\mathrm{CH}_{2}-\right.$ $\left.\mathrm{CH}) \mathrm{n} ;-\mathrm{C}-\left(\mathrm{CH}_{3}\right)_{2}\right), 1.29-1.24\left(\mathrm{~m},\left(-\mathrm{CH}_{2}\right)_{10}\right)-, 0.87-0.84\left(\mathrm{~m},-\mathrm{CH}_{3}\right)$.

Infrared Spectroscopy in Solution - Solutions of pMAA in THF and pHEA in DME at 8 mg.mL ${ }^{-1}$ were prepared by mixing with the solvent at room temperature. Samples of pMAA in DME $\left(8 \mathrm{ml} . \mathrm{mL}^{-1}\right)$ were prepared via sonication in iced water before being allowed to stand at $5^{\circ} \mathrm{C}$ for 24 hours. Further sonication was then undertaken (in iced water) before holding at $5^{\circ} \mathrm{C}$ for a further 12 hours. The resultant clear solution was filtered for IR analysis. The samples were transferred to a Specac ZnSe liquid cell ( 0.5 to $1 \mathrm{~mm}$ path length) fitted into a Specac variable temperature controller (VTC) equipped with $\mathrm{KBr}$ windows. To avoid condensation, the VTC jacket and sample compartment were continuously flushed with argon. The Infrared (IR) spectra of the polymer solutions were recorded in the $400-12000 \mathrm{~cm}^{-1}$ wavenumber region using a Bruker Tensor 27 spectrometer equipped with an extended KBr beamsplitter, DTGS detector and near infrared source. Each spectrum was the accumulation of 32 scans at $4 \mathrm{~cm}^{-1}$ resolution. The spectrum of the empty cell was initially recorded as the background. Transmission spectra of the solution and pure solvent were undertaken and corrected from water vapor. Both pure solvent and solutions were analyzed from $-5{ }^{\circ} \mathrm{C}$ to $55^{\circ} \mathrm{C}$, spectra being recorded at $\sim 5{ }^{\circ} \mathrm{C}$ intervals, each temperature step allowed to equilibrate for $5 \mathrm{~min}$ before spectra gathered. Temperatures were 
controlled via an insertion cold source set at $-30{ }^{\circ} \mathrm{C}$ and equilibrated using the Specac variable temperature cell controller system. The temperature was measured locally with a thermocouple embedded inside the liquid cell frame. For each temperature, the difference of absorbance $A$ (solution)-A(solvent) was plotted. Data was analyzed under the OPUS software, the absorbance signal was decomposed into a sum of single gaussian signals using the "spectral fit" module.

Cloud Point Measurements - Solutions of pMAA and pHEA in DME at $8 \mathrm{mg} \cdot \mathrm{mL}^{-1}$, prepared as above, were filled into $1 \mathrm{~cm}$ path length quartz cells. Light transmission at $\lambda=670 \mathrm{~nm}$ wavelength was measured during an $1^{\circ} \mathrm{C} \cdot \mathrm{min}^{-1}$ heating ramp using a Shimadzu 2401PC UVvisible spectrophotometer equipped with a circulating fluid thermalized trough holder. The sample compartment was flushed with argon throughout the experiment. The sample temperature was measured with a thermocouple in contact with the quartz cell.

Small-angles neutron scattering - SANS experiments were performed on line D22 at the Institute Laue Langevin, Grenoble. Monochromatic $(\lambda=6 \AA)$ radiation was used. Samples were prepared via dissolution in DME- $d_{10}$ as described above. The solutions and pure solvent were held in amorphous silica ("quartz") Hellma cells (optical path: $1 \mathrm{~mm}$, cell volume $=300 \mu \mathrm{L}$ ). The temperature was imposed by a circulating fluid in the cells' holder rack. Data collection at two sample-to-detector distances $D=1.25 \mathrm{~m}$ and $D=5.60 \mathrm{~m}$ permits to cover the scattering wave vector range from $q=0.03 \AA^{-1}$ to $0.5 \AA^{-1}$.

\section{RESULTS}

Homopolymer models, poly(methacrylic acid) (pMAA) and poly(2-hydroxyethyl acrylate) (pHEA) have been prepared for this study. The schematic diagrams showing the synthesis of pMAA and pHEA are given in Figure S1 (Supplementary Information).

Hydroxyethyl acrylate was first purified so as to get rid of contaminating diacrylate ${ }^{17}$, then polymerized by RAFT, following standard procedures. ${ }^{18}$ affording pHEA with the desired low molecular weight and narrow molecular weight distribution: $M_{n}(\mathrm{SEC})=3100 \mathrm{~g} \cdot \mathrm{mol}^{-1} ; M_{w} / M_{n}$ $(\mathrm{SEC})=1.08 ; M_{n}(\mathrm{NMR})=2420 \mathrm{~g} \cdot \mathrm{mol}^{-1}$. Measured $M_{n}$ values correspond to a sequence of about 18 monomers.

RAFT was also used to access to low molecular weight pMAA. In this case, p(tBu)MA intermediately obtained $\left(M_{n}(\mathrm{SEC})=3590 \mathrm{~g} / \mathrm{mol}, M_{w} / M_{n}=1.22\right)$ was end-functionalized by 
thiol-Michael reaction in order to avoid S-S coupling during further processes, DMF was selected as solvent to perform both reactions in one pot, as previously reported. ${ }^{19}$ The obtained compound was then hydrolyzed following previously reported conditions, ${ }^{20}$ giving rise to the desired pMAA sample: $M_{w} / M_{n}(\mathrm{SEC})=1.05 ; M_{n}(\mathrm{NMR})=1714-2058 \mathrm{~g} \cdot \mathrm{mol}^{-1}$. The value of $M_{n}$ measured by NMR corresponds to a sequence of about $\mathrm{n} \approx 17-21$ monomer units. The apparent larger value of $M_{n}$ measured by SEC in water is probably due to the more extended conformation of this polymer, which is ionized at $\mathrm{pH}=6$. The relatively narrow molecular weight distributions for both polymers (dispersity index $(\mathrm{PDI}) \leq 1.2$ ) demonstrates good control over the polymerization of HEA and MAA via RAFT.

Here, we study the solubility behavior of pMAA and pHEA in 1,2-dimethoxyethane (DME) and tetrahydrofurane (THF). The chemical structures of these two polymers are given in Scheme 1. In the bulk state pMAA is a solid powder whereas pHEA is a viscous liquid.
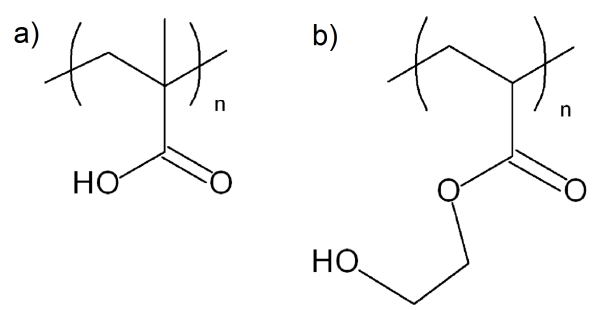

Scheme 1. Chemical structure of a) poly(methacrylic acid) (pMAA) and b) poly(2-hydroxyethyl acrylate) (pHEA); $\mathrm{n} \approx 18$ in both samples.

The visual aspect of the pMAA solution in DME just from the refrigerator and after warming between hands is shown in Figure 1a. The polymer solution became turbid, meaning that phase separation occurred when heating it, thus simply illustrating the Low Critical Solution Temperature (LCST) behavior of pMAA in DME.

In the case of pHEA, the solution remains always transparent without evident effect of temperature, i.e. it is not thermoresponsive. Even if both polymers are soluble at $T<25^{\circ} \mathrm{C}$, pHEA dissolves readily, whereas pMAA requires sonication and refrigeration before an optically transparent solution is obtained. The thermoresponsive properties of pMAA are quantified by cloud point measurements at wavelength of $670 \mathrm{~nm}$, using an UV-visible spectrophotometer. For this purpose, polymer solutions of pHEA and pMAA in DME $\left(c=8 \mathrm{mg} \cdot \mathrm{mL}^{-1}\right)$ were heated between 5 and $60{ }^{\circ} \mathrm{C}$ at $1{ }^{\circ} \mathrm{C} \cdot \mathrm{min}^{-1}$, the optical transmittance through a path length of $1 \mathrm{~cm}$ is 
plotted as a function of temperature (Figure 1b). The cloud point, corresponding to the LCST value, was defined as the point of $50 \%$ transmittance. In the case of pHEA, transmittance of the solution is constant; showing that pHEA remains completely soluble over the whole temperature range. As for pMAA, the transmittance of the solution decreases when heating the sample showing the phase separation. The LCST of this solution is in the range of $21-26^{\circ} \mathrm{C}$. This temperature range is much lower than the boiling point of the DME $\left(85^{\circ} \mathrm{C}\right)$, thus the LCST behavior in this system is obviously not related to near-critical compressibility effects. Upon further heating, around $45^{\circ} \mathrm{C}$ it is observed that the optical transmission of the cell re-increases, due to sedimentation of the polymer-rich phase. Phase transition of pMAA in DME is found to be fully reversible by cooling-heating cycles. The LCST behavior of pMAA is not observed in THF where it appears to be fully soluble.

a)

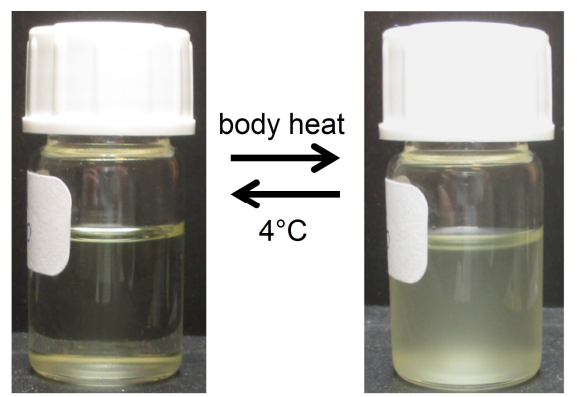

b)

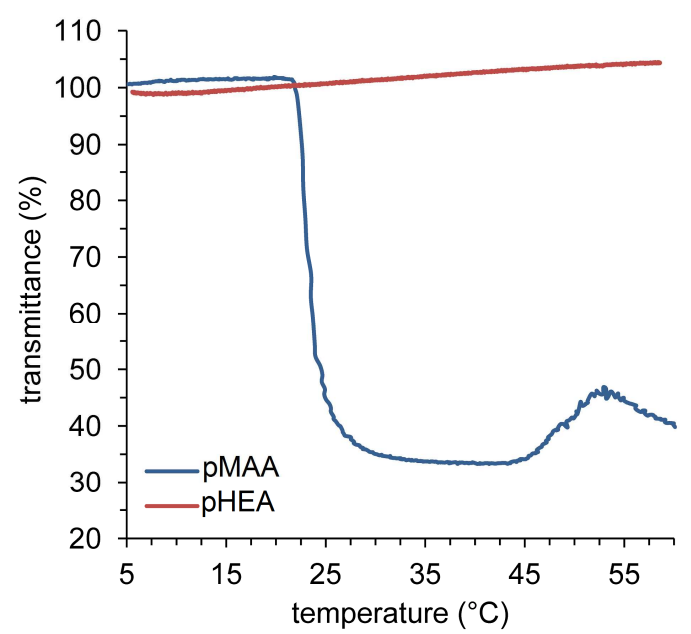

Figure 1. a) Demonstration of the LCST property at ambient temperatures by warming vials between hands. b) Transmittance at $670 \mathrm{~nm}$ through a pathlength of $1 \mathrm{~cm}$ of pMAA (blue) and pHEA (red) solutions in DME at $8 \mathrm{mg} \cdot \mathrm{mL}^{-1}$ as a function of temperature (heating rate: $1^{\circ} \mathrm{C} \cdot \mathrm{min}^{-1}$ ).

In order to evidence the specific interactions that occur within the polymers chains and the solvent during the LCST, FT-IR spectra of the pMAA and pHEA solutions $\left(8 \mathrm{mg} \cdot \mathrm{mL}^{-1}\right)$ in DME and in THF were recorded in the temperature range of -10 to $55^{\circ} \mathrm{C}$. Both solvents present two transparency windows in the infrared: one in Near-Infrared (NIR) region between 12000 and $3500 \mathrm{~cm}^{-1}$ and one in mid-infrared (MIR) region between 2000 and $1600 \mathrm{~cm}^{-1}$. NIR observations 
allow analysis of solution turbidity at various temperatures, and thus in situ LCST determination. ${ }^{21}$ Concurrently, MIR analysis allows important structural changes to be monitored throughout the LCST phase separation by observing shifts in the hydrogen bound and free carbonyl stretch absorbances. $^{22}$

The NIR spectra of pMAA in DME (Figure 2a) show an increase of absorbance when rising the temperature from -10 to $38^{\circ} \mathrm{C}$, this is directly associated with an increase in the opacity of the solution in agreement with visual observations and transmittance measurements in the visible range. At $\mathrm{T}>38^{\circ} \mathrm{C}$, it was observed a decrease of absorbance related to the aggregation and sedimentation of the polymer chains. In order to determine the LCST value, absorbance at 10000 $\mathrm{cm}^{-1}$ was plotted versus temperature (Figure $2 b$ ). The LCST region for this system is around 20$29^{\circ} \mathrm{C}$, which is in agreement with UV-visible measurements.
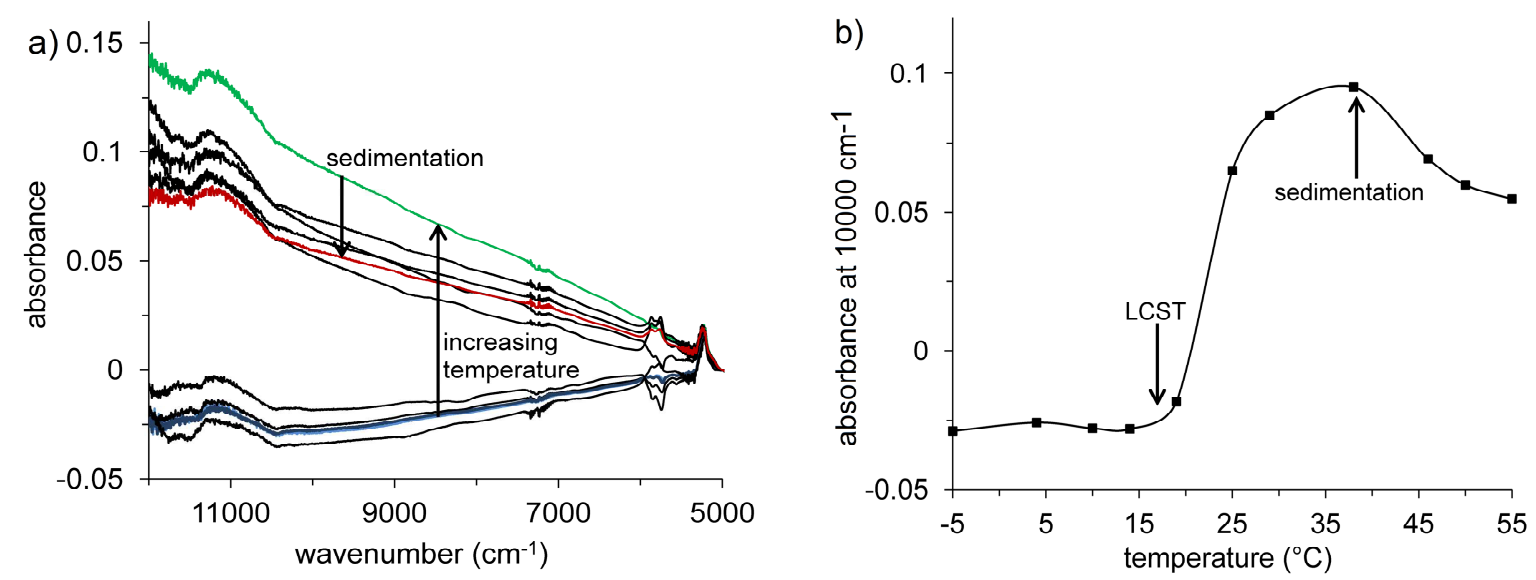

Figure 2. a) NIR spectra of pMAA in DME $\left(8 \mathrm{mg} \cdot \mathrm{mL}^{-1}\right)$ from $-10^{\circ} \mathrm{C}$ to $55^{\circ} \mathrm{C}$, demonstrating the LCST behavior (blue, green and red lines represent spectra at $-5,38$ and $55^{\circ} \mathrm{C}$ respectively). b) Absorbance at $10000 \mathrm{~cm}^{-1}$ of pMAA in DME versus temperature.

As for the MIR region, a concern was to ensure the purity of the solvent, because degradation products of DME, probably due to oxidation, ${ }^{22}$ show an absorption band at $1730 \mathrm{~cm}^{-1}$, which can be confused with that of the polymer (the effects of water and solvent impurities on MIR spectra are reported in ESI). In the region of $\mathrm{C}=\mathrm{O}$ stretching vibrations $\left(1575-1850 \mathrm{~cm}^{-1}\right)$, absorbance spectra at different temperatures from -10 to $55^{\circ} \mathrm{C}$ were fitted by a sum of gaussian peaks in 
order to analyze the effect of hydrogen bonding. Figure 3 shows infrared spectra and the result of the gaussian fit at two temperatures, $10{ }^{\circ} \mathrm{C}$ and $50{ }^{\circ} \mathrm{C}$ for pMAA/DME (Figure 3a-b) and pHEA/DME solutions (Figure 3c-d).
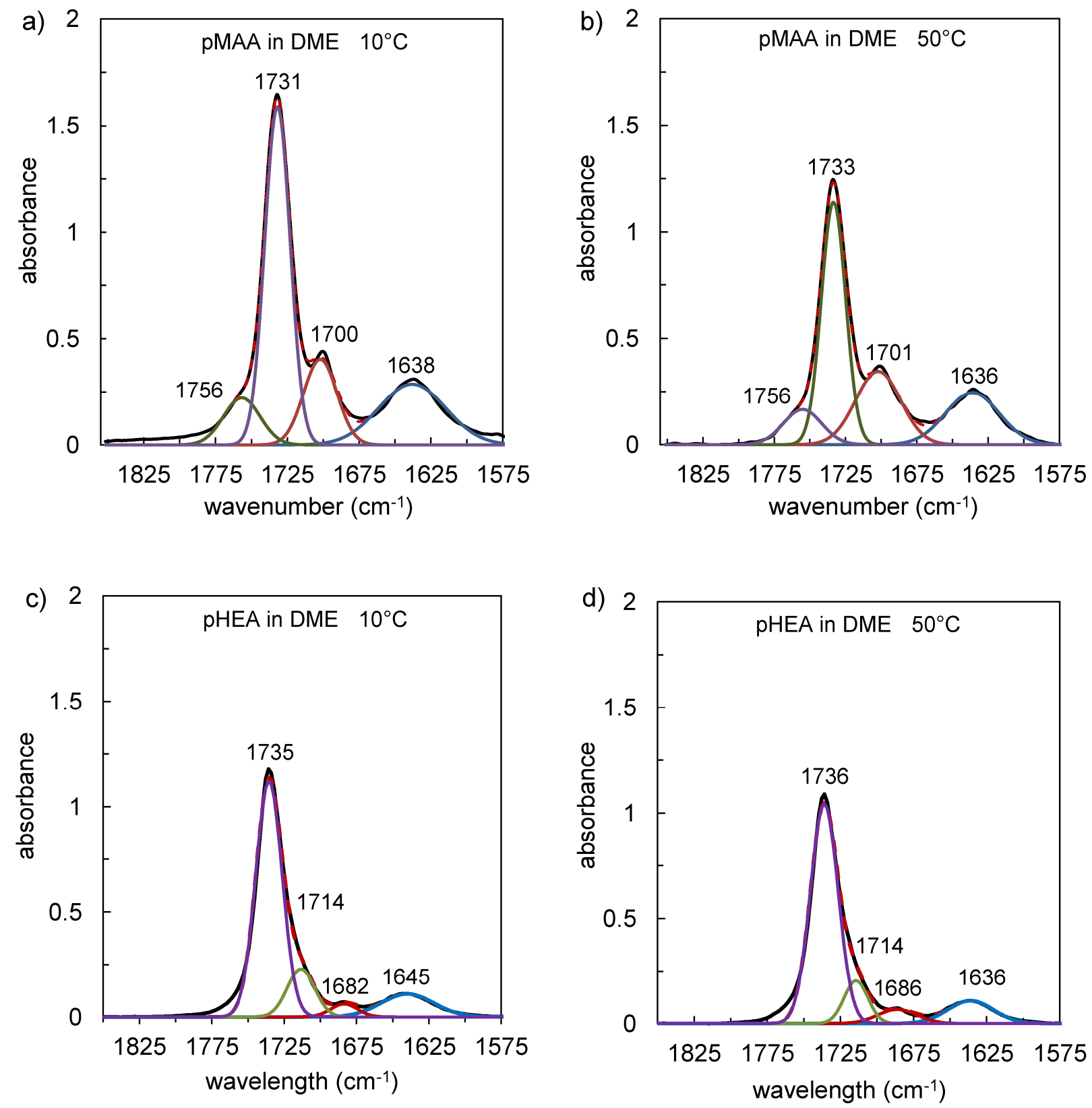

Figure 3. MIR spectra of pMAA in DME solutions at a) 10 and b) $50{ }^{\circ} \mathrm{C}$; and pHEA in DME solutions at c) 10 and d) $50^{\circ} \mathrm{C}\left(8 \mathrm{mg} \cdot \mathrm{mL}^{-1}\right)$. 
Concerning the pMAA in DME solution, we always obtained three bands that best fit the $\mathrm{C}=\mathrm{O}$ envelope, for all the spectra recorded from -10 to $55^{\circ} \mathrm{C}$. The three main absorption peaks are detected at respectively $v=1700,1731$ and $1756 \mathrm{~cm}^{-1}$ (Figure 3a-b). Peak at $1700 \mathrm{~cm}^{-1}$ is typical of dimerized $-\mathrm{COOH}$ moieties via hydrogen bonds between $\mathrm{C}=\mathrm{O}$ and $-\mathrm{OH}$ groups, peak at 1731 $\mathrm{cm}^{-1}$ is in the range of intramolecular hydrogen bonding and the peak at $1756 \mathrm{~cm}^{-1}$ corresponds to the free carbonyl vibration (non hydrogen-bonded). ${ }^{22}$ These peaks are present at all temperatures, but the area under the peaks varies as temperature increases. The plot presented in Figure $4 \mathrm{a}$ shows the relative integrals normalized for different absorbance peak for pMAA in DME. It is shown that the relative integral of the peak at $1700 \mathrm{~cm}^{-1}$ increases, when the relative integral of the peak at $1731 \mathrm{~cm}^{-1}$ decreases, which means that the number of dimerized $\mathrm{COOH}$ moieties increases, at the same time the number of intramolecular hydrogen bonding decreases. In contrast, the relative integrals of the same bands are essentially constant in THF where no LCST was observed (Figure 4b). The peak at $1638 \mathrm{~cm}^{-1}$ was recognized as traces of water in the organic solvent.

For pHEA in DME solution, the $\mathrm{C}=\mathrm{O}$ stretching region was well fitted assuming two gaussian contributions; the peak at $1714 \mathrm{~cm}^{-1}$ represents the hydrogen-bonded $\mathrm{C}=\mathrm{O}$ with $-\mathrm{OH}$ and the peak at $1735 \mathrm{~cm}^{-1}$ correspond to the free carbonyl vibration (Figure $3 \mathrm{c}-\mathrm{d}$ ). ${ }^{23}$ These peaks are presents at all temperatures, but the area under the peaks remains nearly constant when the temperature increases. The evolution of the relative integrals normalized for pHEA in DME is very weak (Figure 4c), which is in agreement with a good solubility of pHEA in this solvent and non-observation of LCST for all studied temperatures. 

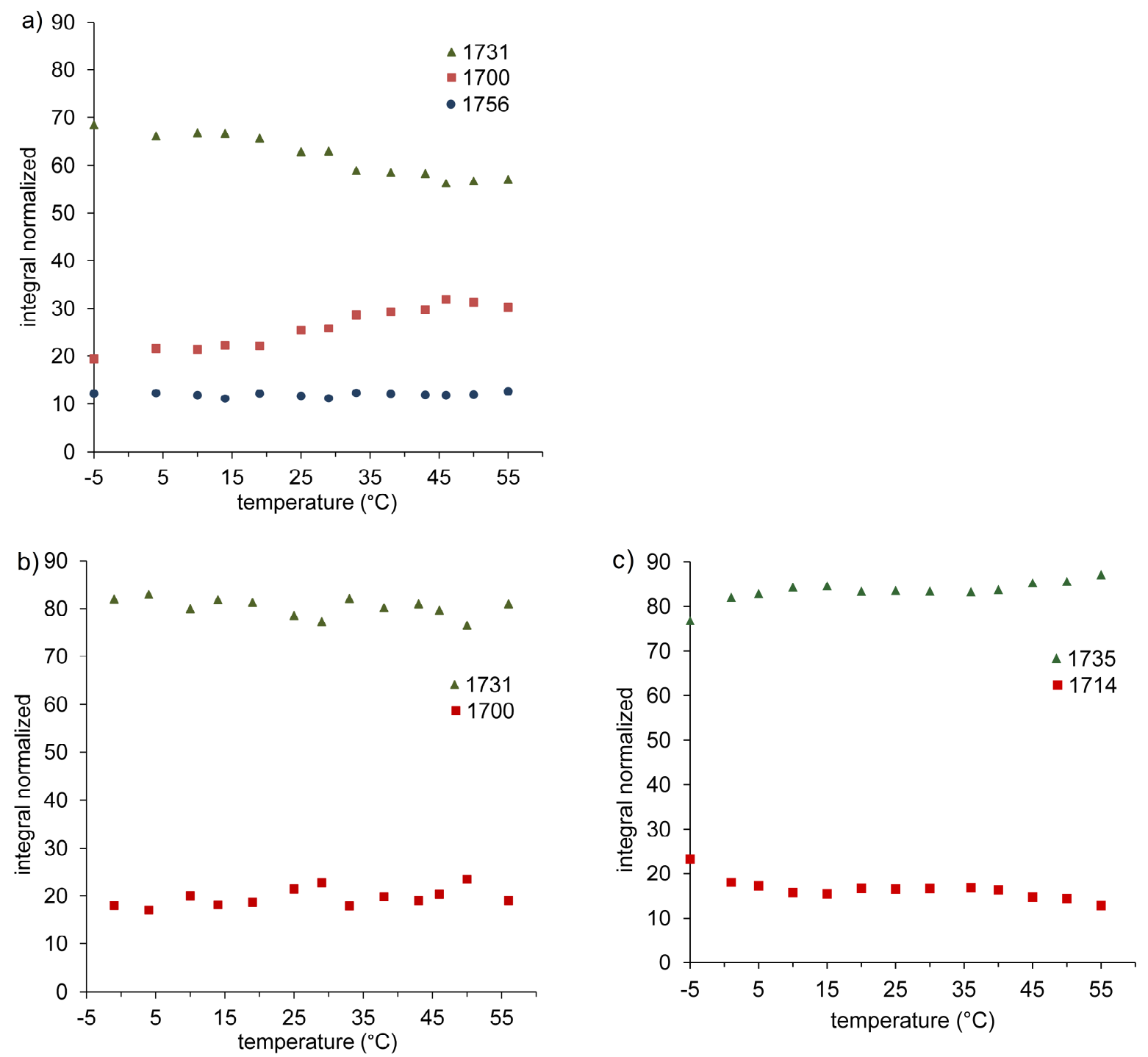

Figure 4. Relative integrals normalized for a) pMAA in DME, b) pMAA in THF and c) pHEA in DME solutions plotted from the absorption peaks in the mid-infrared region.

Figure 5 shows the SANS analysis of pMAA and pHEA solutions in DME at $8 \mathrm{mg} \cdot \mathrm{mL}^{-1}$ at $0^{\circ} \mathrm{C}$. The SANS curves concerning the other temperatures $\left(0,4,9,15,25\right.$ and $\left.39{ }^{\circ} \mathrm{C}\right)$ are given in Figure S7 (Supplementary Information). The radius of gyration, $R_{g}$ was determined using the Debye model equation:

$$
I(q)=I(0) 2 \frac{\exp \left(-q^{2} R_{g}^{2}\right)+q^{2} R_{g}^{2}-1}{\left(q^{2} R_{g}^{2}\right)^{2}}
$$

Eq. 1

At $0^{\circ} \mathrm{C}$, the average radii of gyration $R_{g}$ of pMAA and pHEA are of respectively 14.5 and 13.1 $\AA$, while at $25^{\circ} \mathrm{C}$ it is of respectively 16.0 and $13.0 \AA$. Upon increase of temperature, we 
observed that $R_{g}$ of pHEA remains constant or slightly decreases, while $R_{g}$ of pMAA continuouly increases up to the LCST (Figure 5c). Above the LCST, the scattered intensity of the pMAA solution drops (Figure 5a2), which is in agreement with sedimentation of precipitated polymer chains upon heating. Moreover it was observed that $R_{g}$ also drops above the LCST to resume the value measured at $5^{\circ} \mathrm{C}$. Due to sedimentation, the value measured above LCST refers to a smaller polymer concentration. The fact that it is smaller proves that the apparent increase in $R_{g}$ approaching the LCST is due to the gradual aggregation of pMAA chains.
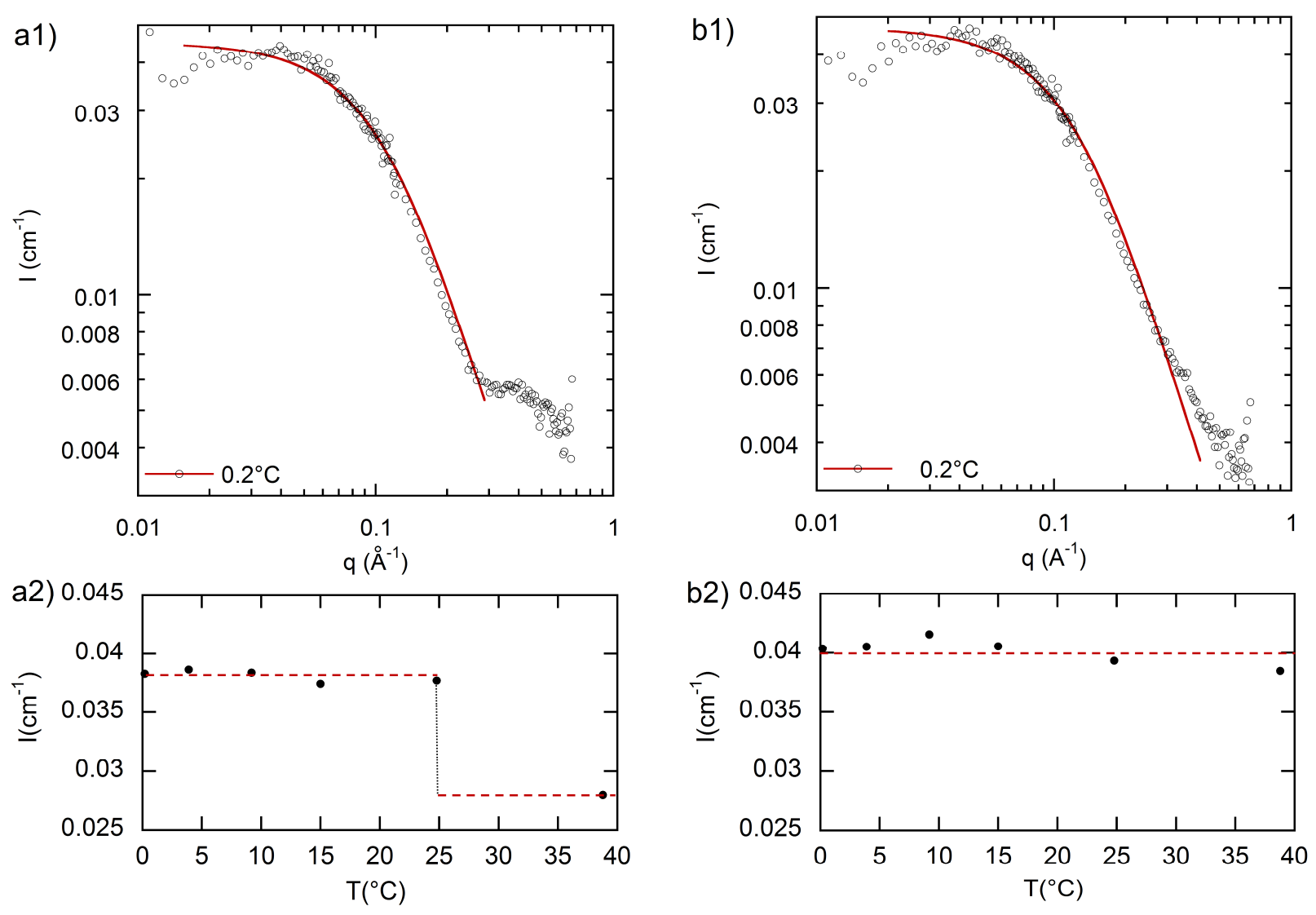


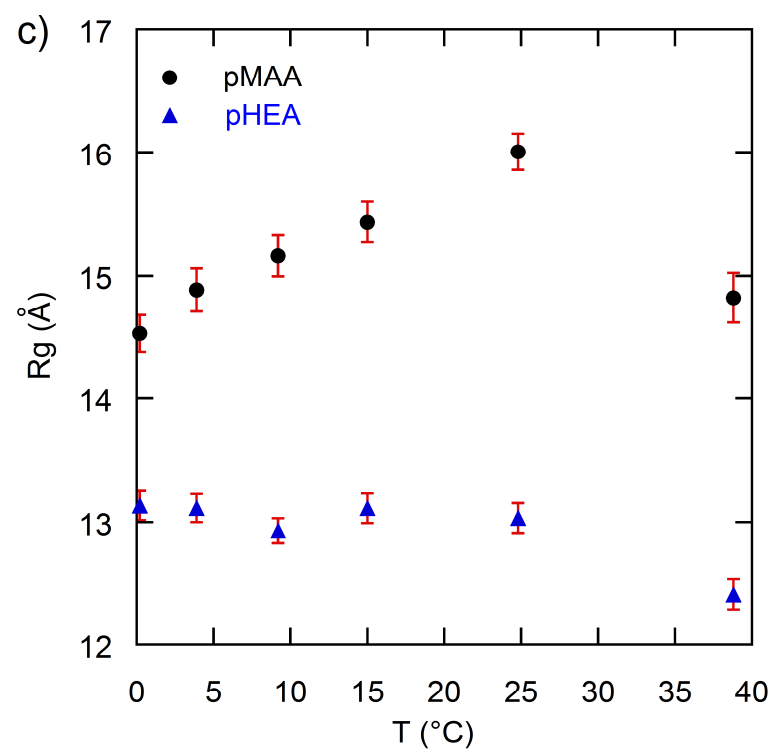

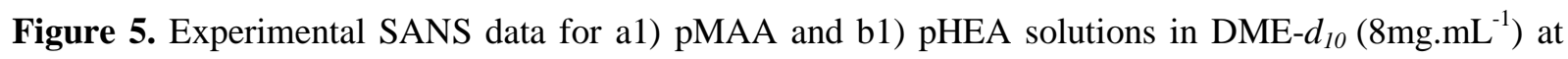
$0.2^{\circ} \mathrm{C}$ (empty dark cercles). Data was fitted by Debye function (red line). The intensity scattering (at $\mathrm{q}=$ $0.05 \AA^{-1}$ ) versus the temperature of a2) pMAA and b2) pHEA solutions are also plotted. c) Evolution of $\operatorname{Rg}(\AA)$ of pMAA and pHEA solutions versus the temperature (from 0 to $38^{\circ} \mathrm{C}$ ). 


\section{DISCUSSION}

Historically, the first models that explained the LCST in solvent-polymer systems were based on descriptions that take into account the difference in compressibility between the two components. ${ }^{24}$ These models are relevant in the vicinity of the liquid-vapor critical point of the solvent or for very high molecular weight polymers, which is not the case here. Alternatively, the unfavorable (negative) entropy of mixing, responsible for the LCST, is associated to strong polar interactions or hydrogen bonds, which prevent random mixing.

pMAA and pHEA are water-soluble polymers that both contain strongly polar and hydrogenbonding groups. Lee et al. ${ }^{25}$ Erreur ! Signet non défini. ${ }^{24}$ performed a detailed study of the solubility behavior of pMAA in organic solvents and determined experimentally the threedimensional Hansen's solubility parameters ${ }^{26}$ of pMAA $\left(\delta_{d}=17.3 ; \delta_{p}=12.4 ; \delta_{h}=15.9 \mathrm{~J}^{1 / 2} . \mathrm{cm}^{-}\right.$ ${ }^{3 / 2}$ ). Based on this work, the projections of the solubility region of pMAA in the $\delta_{d}-\delta_{p}$ and $\delta_{h}-\delta_{p}$ planes have been plotted in Figure S7 (Supplementary Information); a simplified version is presented in Figure 6.

In this region, the most suitable solvents for pMAA are protic solvents, such as ethanol, ethanol amine, 2-ethoxyethanol (ethyl cellosolve), 1-propanol and diethylene glycol; as well as strongly polar aprotic solvents such as dimethyl sulfoxide, N,N-dimethyl formamide, N,Ndimethylacetamide. However, pyridine, which is a weakly polar aprotic solvent, remains a good solvent for pMAA, even though its parameters are clearly outside the Hansen solubility region. It is well known that carboxylic acid groups and pyridine molecules form stable hydrogen-bonded complexes in bulk, as described by Kato et al. ${ }^{27-29}$. In the present case, this suggests that it is a pMAA-pyridine complex rather than pMAA alone which is soluble in pyridine. 

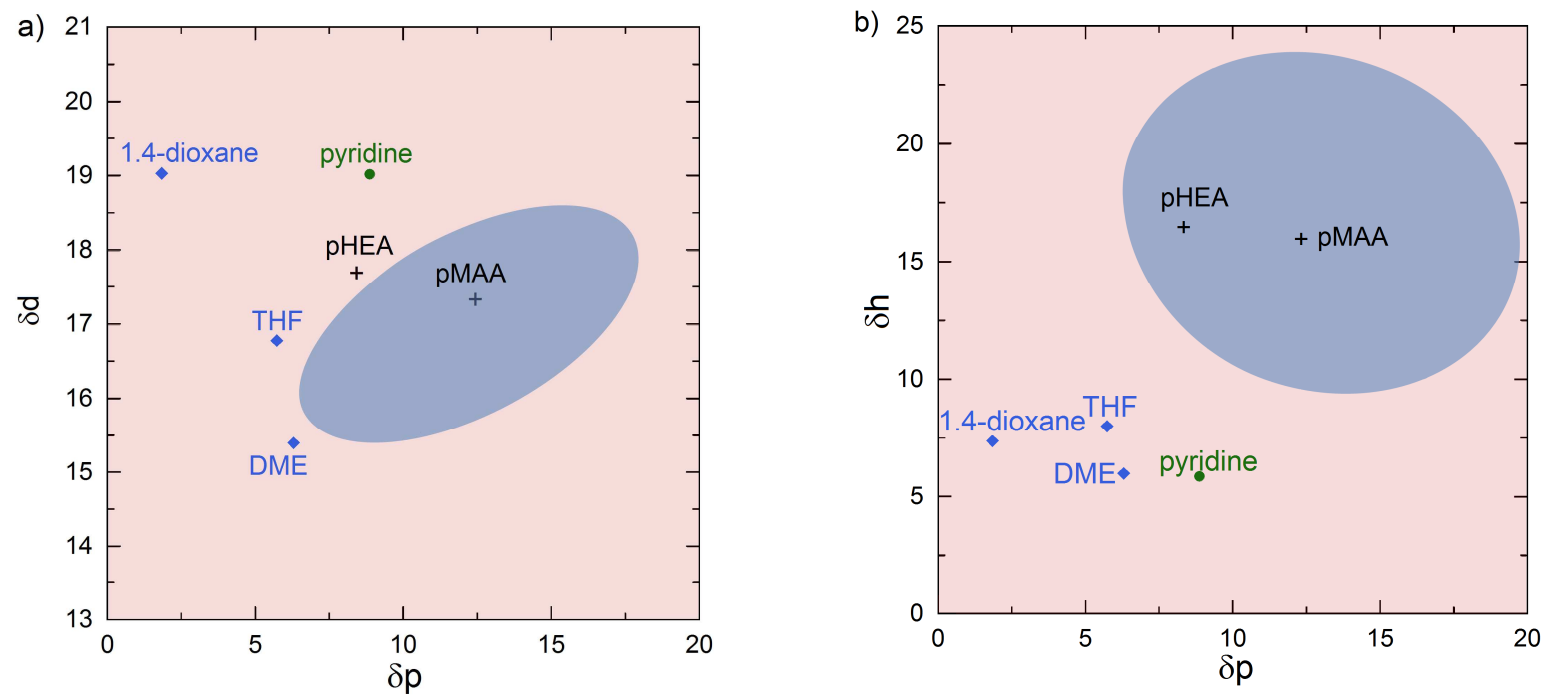

Figure 6. Projections of the solubility sphere of pMAA (blue region: good solubility, red region: non solubility) in the a) $\delta_{d}-\delta_{p}$ and b) $\delta_{h}-\delta_{p}$ planes, based on the results of ref 24 . Solvents such as, 1,4dioxane, tetrahydrofurane (THF), 1,2-dimethoxyethane (DME) and pyridine, although located outside the Hansen solubility sphere are capable of solubilising pMAA and pHEA at $8 \mathrm{mg} \cdot \mathrm{mL}^{-1}$.

As for, pHEA, only the calculated Hansen solubility parameters were found in the literature: ${ }^{30}$ $\left(\delta_{d}=17.7 ; \delta_{p}=8.4 ; \delta_{h}=16.6 \mathrm{~J}^{1 / 2} \cdot \mathrm{cm}^{-3 / 2}\right)$ These values place pHEA close to the boundaries of the solubility region of pMAA (Figure 6).

By studying the solubility properties of pMAA and pHEA oligomers ( $n \approx 18$ monomers) in various organic solvents, we observed that three other solvents, 1,2-dimethoxyethane (DME), tetrahydrofurane (THF) and 1,4-dioxane, also located outside the solubility region of pMAA are able to solubilize these polymers at the concentration of $8 \mathrm{mg} \cdot \mathrm{mL}^{-1}$. All these solvents, like pyridine, are weakly polar and aprotic; they are hydrogen bond acceptors and not donors. Thus, all these solvents have the ability to form hydrogen bond links to pMAA and to pHEA, but no ability to form the same type of links with themselves.

Such links have a pronounced directional character: a H-bond is formed only for a certain orientation of the chemical groups that interact. Once the bond is formed, a large number of orientational degrees of freedom become frozen. Therefore, solvent-polymer links through $\mathrm{H}-$ 
bonds are energetically favorable to the mixing, but entropically unfavorable, which causes the LCST behavior to happen. ${ }^{31}$ For the LCST of pMAA in DME, the thermal dependence of $\mathrm{C}=\mathrm{O}$ stretching absorptions supports this interpretation, showing the progressive decrease in the number of polymer-solvent links and the gradual appearance of rather stable polymer-polymer links through doubly H-bonded dicarboxylic dimers. On the other hand, SANS results demonstrate that this polymer tends to aggregate even before the onset of phase separation. This fact may be related to the known tendency of this polymer to also aggregate in water at low $\mathrm{pH}$ and weak ion strength, a property that has been attributed to zipper-type hydrogen-bonding interactions that can take place when regularly spaced acid functions are not neutralized. ${ }^{22,32-34}$ This mechanism could explain the trend of aggregation noted here.

The LCST behavior of pMAA in DME is not observed neither in 1,4-dioxane, not in THF. Thus, it is a very subtle chemical equilibrium between pMAA and DME, where the internal flexibilities of the solvent's molecule seem to play a part in the LCST phenomenon. If we compare the chemical structure of these three solvents, it is clear that 1,4-dioxane and THF, having a cyclic structure, are more rigid than DME, which have a more flexible linear structure. Thus, in DME more degrees of freedom (rotation around $\mathrm{C}-\mathrm{O}$ and $\mathrm{C}-\mathrm{C}$ bonds) are concerned, making solventpolymer links more unfavorable, entropically.

As for pHEA, its solubility range seems rather similar to that of pMAA, the mechanisms detailed above could just as easily be applied, implying that there might be an LCST. During heating, it is found that the polymer chain shrinks weakly, suggesting the solvent quality deteriorates but without tendency to form aggregates. Indeed, even in bulk, this polymer has no tendency to aggregate: while for pMAA, it is possible to precipitate the polymer and collect it as a solid powder, the same is not possible with pHEA which remains a viscous liquid. Its particular behavior in solution seems therefore due to the absence of polymer-polymer links as cooperative as in pMAA and to the presence of the flexible side chains, that prevent aggregation through entropic forces.

\section{CONCLUSIONS}

In the present work, two homopolymers systems, pMAA/solvent and pHEA/solvent, were studied such as model systems in order to show how the interaction between the polymer and the 
solvent can lead to negative entropy of mixing. Simultaneous near and medium IR as well as SANS measurements were undertaken to evaluate hydrogen-bonding, aggregation and phase separation in pMAA and pHEA solutions in two organic solvents (DME and THF). At $T<$ LCST, pMAA chains are in a solvated form in DME. Solvation through formation of hydrogen bonds involves a reduction of the rotational and conformational degrees of freedom of the solvent, all the more the solvent has internal flexibility. At $T>$ LCST, desolvation takes place, for entropic reasons and chains aggregate through formation of cooperative hydrogen bonds.

The same is not true in pHEA where aggregation is prevented by the flexibility of the polymer side chains.

Understanding the LCST mechanism in pMAA/DME solutions could enlighten the more complex scenario of LCST in alternating sequence-controlled copolymer solutions in organic solvents. ${ }^{35-37}$ These homopolymers systems, pMAA and pHEA, are the elementary bricks of random and alternating sequence-controlled methacrylic acid/hydroxyethyl acrylate copolymers, noted respectively $\mathrm{p}(\mathrm{MAA}-\mathrm{co}-\mathrm{HEA})$ and $\mathrm{p}(\mathrm{MAA}-$ alt-HEA $){ }^{13}$ where the differences in sequence seem to play a key part. A distinctive feature of the random copolymer is the presence of homoblocks AA, AAA, AAAA, etc, that cannot exist in the alternating copolymer. We conclude that this is the presence of pHEA homoblocks that maintains solubility and prevents occurrence of the LCST in the random copolymer.

\section{ASSOCIATED CONTENT}

\section{Supporting Information.}

The Supporting Information is available free of charge on the ACS Publications website at DOI: XXXXX

Synthetic scheme of homopolymers poly(methacrylic acid) (pMAA) and poly(hydroxyl ethyl acrylate) (pHEA). ${ }^{1} \mathrm{H}$ NMR spectra of poly(2-hydroxyethyl acrylate) (pHEA) in DMSO- $d_{6 .}{ }^{1} \mathrm{H}$ NMR spectra of poly(methacrylic acid) (pMAA) in DMSO- $d_{6}$. FT-IR spectrum of pHEA in bulk at $25{ }^{\circ} \mathrm{C}$. FT-IR spectrum of pMAA in bulk at $50{ }^{\circ} \mathrm{C}$. SANS data for pMAA and pHEA solutions in DME- $d_{10}$ (at $8 \mathrm{mg} \cdot \mathrm{mL}^{-1}$ ) at temperatures from 0 to $39^{\circ} \mathrm{C}$. Projections of the solubility sphere of pMAA in 55 solvents and the solubility region of pMAA in the $\delta_{d^{-}} \delta_{p}$ and $\delta_{h^{-}} \delta_{p}$ plane. 
Neutron scattering data are available on the ILL website at

DOI:10.5291/ILL-DATA.DIR-158. 2018

\section{AUTHOR INFORMATION}

\section{Corresponding Author}

*Email: francois.tournilhac@espci.fr

\section{Present Addresses}

$\dagger$ Benjamin C. Baker : University of Bristol, School of Chemistry, Cantock's Close Clifton Bristol, UK.

\section{Author Contributions}

The manuscript was written through contributions of all authors. All authors have given approval to the final version of the manuscript.

\section{ORCID}

Esther Cazares-Cortes: 0000-0002-2215-0291

Benjamin C. Baker: 0000-0003-4829-6755

Kana Nishimori: 0000-0003-4980-6411

Makoto Ouchi: 0000-0003-4540-7827

François Tournilhac: 0000-0002-6775-1584

\section{Notes}

The authors declare no competing financial interest.

\section{ACKNOWLEDGMENT}

This work was partially supported by the French National Research Agency (ANR) and the Japanese Science and Technology Agency (JST). Renaud Nicolaÿ is thanked for his advices in RAFT polymerizations. Institut Laue-Langevin (ILL) Grenoble, is acknowledged for provision of beamtime. Lionel Porcar is thanked for his helpful contributions in experiments and data analyses. Ludwik Leibler and Bogdan Tarus are thanked for helpful discussions. 


\section{REFERENCES}

(1) Stuart, M. A. C.; Huck, W. T. S.; Genzer, J.; Müller, M.; Ober, C.; Stamm, M.; Sukhorukov, G. B.; Szleifer, I.; Tsukruk, V. V.; Urban, M.; et al. Emerging Applications of Stimuli-Responsive Polymer Materials. Nat. Mater. 2010, 9 (2), 101-113. https://doi.org/10.1038/nmat2614.

(2) Wei, M.; Gao, Y.; Li, X.; Serpe, M. J. Stimuli-Responsive Polymers and Their Applications. Polym. Chem. 2016, 8 (1), 127-143. https://doi.org/10.1039/C6PY01585A.

(3) Hibi, Y.; Tokuoka, S.; Terashima, T.; Ouchi, M.; Sawamoto, M. Design of AB Divinyl "Template Monomers" toward Alternating Sequence Control in Metal-Catalyzed Living Radical Polymerization. Polym. Chem. 2011, 2 (2), 341-347. https://doi.org/10.1039/COPY00252F.

(4) Terashima, T.; Kawabe, M.; Miyabara, Y.; Yoda, H.; Sawamoto, M. Polymeric PseudoCrown Ether for Cation Recognition via Cation Template-Assisted Cyclopolymerization. Nat. Commun. 2013, 4, 2321. https://doi.org/10.1038/ncomms3321.

(5) Hibi, Y.; Ouchi, M.; Sawamoto, M. Sequence-Regulated Radical Polymerization with a Metal- Templated Monomer: Repetitive ABA Sequence by Double Cyclopolymerization. Angew. Chem. Int. Ed. 2011, 50 (32), 7434-7437. https://doi.org/10.1002/anie.201103007.

(6) Sedlák, M. A Novel Approach to Controlled Self-Assembly of PH-Responsive Thermosensitive Homopolymer Polyelectrolytes into Stable Nanoparticles. Adv. Colloid Interface Sci. 2016, 232, 57-69. https://doi.org/10.1016/j.cis.2015.12.005.

(7) Victor, S. P.; Sharma, C. P. Stimuli Sensitive Polymethacrylic Acid Microparticles (PMAA) - Oral Insulin Delivery. J. Biomater. Appl. 2002, 17 (2), 125-134. https://doi.org/10.1106/088532802028583.

(8) Sonia, T. A.; Sharma, C. P. Oral Delivery of Insulin; Elsevier Science \& Technology: Cambridge, United Kingdom, 2014.

(9) Freeman, P. I.; Rowlinson, J. S. Lower critical points in polymer solutions. Polymer, 1960, 1, 20-26. https://doi.org/10.1016/0032-3861(60)90004-5.

(10) Flory, P. J.; Osterheld, J. E.; Intrinsic Viscosities of Polyelectrolytes. Poly-(Acrylic Acid) J. Phys. Chem. , 1954, 58 (8), 653-661. https://doi.org/10.1021/j150518a014

(11) Miller, M. L.; O’Donnell, K.; Skogman, J. Crystalline Polyacrylic Acid. J. Colloid Sci. 1962, 17 (7), 649-659. https://doi.org/10.1016/0095-8522(62)90029-6. 
(12) Cowie, J. M. G.; Swinyard, B. Location of Three Critical Phase Boundaries in Poly(Acrylic Acid)-Dioxane Solutions. Polymer 1990, 31 (8), 1507-1513. https://doi.org/10.1016/00323861(90)90158-U.

(13) Ouchi, M.; Nakano, M.; Nakanishi, T.; Sawamoto, M. Alternating Sequence Control for Carboxylic Acid and Hydroxy Pendant Groups by Controlled Radical Cyclopolymerization of a Divinyl Monomer Carrying a Cleavable Spacer. Angew. Chem. Int. Ed. 2016, 55 (47), 14584-14589. https://doi.org/10.1002/anie.201607169.

(14) García, D. M.; Escobar, J. L.; Bada, N.; Casquero, J.; Hernáez, E.; Katime, I. Synthesis and Characterization of Poly(Methacrylic Acid) Hydrogels for Metoclopramide Delivery. Eur. Polym. J. 2004, 40 (8), 1637-1643. https://doi.org/10.1016/j.eurpolymj.2004.03.011.

(15) Wojtkowiak, B.; Chabanel, M. Spectroscopie Moléculaire. Technique et Documentation, Paris, 1977.

(16) Vargün, E.; Usanmaz, A. Polymerization of 2-Hydroxyethyl Acrylate in Bulk and Solution by Chemical Initiator and by ATRP Method. J. Polym. Sci. Part A Polym. Chem. 2005, 43 (17), 3957-3965. https://doi.org/10.1002/pola.20867.

(17) Coca, S.; Jasieczek, C. B.; Beers, K. L.; Matyjaszewski, K. Polymerization of Acrylates by Atom Transfer Radical Polymerization. Homopolymerization of 2-Hydroxyethyl Acrylate. J. Polym. Sci. Part Polym. Chem. 36 (9), 1417-1424. https://doi.org/10.1002/(SICI)10990518(19980715)36:9<1417::aid-pola9>3.0.co;2-p.

(18) Le Neindre, M.; Magny, B.; Nicolaÿ, R. Evaluation of Thiocarbonyl and Thioester Moieties as Thiol Protecting Groups for Controlled Radical Polymerization. Polym. Chem. 2013, 4 (22), 5577-5584. https://doi.org/10.1039/c3py00754e.

(19) Le Neindre, M.; Nicolaÿ, R. One-Pot Deprotection and Functionalization of Polythiol Copolymers via Six Different Thiol-X Reactions. Polym. Int. 2014, 63 (5), 887-893. https://doi.org/10.1002/pi.4665.

(20) Giebeler, E.; Stadler, R. ABC Triblock Polyampholytes Containing a Neutral Hydrophobic Block, a Polyacid and a Polybase. Macromol. Chem. Phys. 1997, 198 (12), 3815-3825. https://doi.org/10.1002/macp.1997.021981204.

(21) Dall'Olmo, G.; Gitelson, A. A.; Rundquist, D. C.; Leavitt, B.; Barrow, T.; Holz, J. C. Assessing the Potential of SeaWiFS and MODIS for Estimating Chlorophyll Concentration 
in Turbid Productive Waters Using Red and Near-Infrared Bands. Remote Sens. Environ. 2005, 96 (2), 176-187. https://doi.org/10.1016/j.rse.2005.02.007.

(22) Dong, J.; Ozaki, Y.; Nakashima, K. Infrared, Raman, and Near-Infrared Spectroscopic Evidence for the Coexistence of Various Hydrogen-Bond Forms in Poly(Acrylic Acid). Macromolecules 1997, 30 (4), 1111-1117. https://doi.org/10.1021/ma960693x.

(22bis) Carboni, M.; Marrani, A. G.; Spezia, R.; Brutti, S.; 1,2-Dimethoxyethane Degradation Thermodynamics in Li-O ${ }_{2}$ Redox Environments, Chem. Eur. J. 2016, 22, 17188 - 17203. http://doi.org/10.1002/chem.201602375

(23) Morita, S. Hydrogen-Bonds Structure in Poly(2-Hydroxyethyl Methacrylate) Studied by Temperature-Dependent Infrared Spectroscopy. Front. Chem. 2014, 2. https://doi.org/10.3389/fchem.2014.00010.

(24) P. J. Flory, P. J.; Orwoll, R. A.; Vrij, A. Statistical Thermodynamics of Chain Molecule Liquids. II. Liquid Mixtures of Normal Paraffin Hydrocarbons, 1964 J. Am. Chem. Soc., 86, 3515-3520. https://doi.org/10.1021/ja01071a024

(25) Ho, B.-C.; Chin, W.-K.; Lee, Y.-D. Solubility Parameters of Polymethacrylonitrile, Poly(Methacrylic Acid) and Methacrylonitrile/Methacrylic Acid Copolymer. J. Appl. Polym. Sci. 42 (1), 99-106. https://doi.org/10.1002/app.1991.070420112.

(26) Hansen, C. M. Hansen Solubility Parameters $\square$ : A User's Handbook; CRC Press, 2000.

(27) Kato, T.; Frechet, J. M. J. Stabilization of a Liquid-Crystalline Phase through Noncovalent Interaction with a Polymer Side Chain. Macromolecules 1989, 22 (9), 3818-3819. https://doi.org/10.1021/ma00199a060.

(28) Kato, T.; Kihara, H.; Uryu, T.; Fujishima, A.; Frechet, J. M. J. Molecular Self-Assembly of Liquid Crystalline Side-Chain Polymers through Intermolecular Hydrogen Bonding. Polymeric Complexes Built from a Polyacrylate and Stilbazoles. Macromolecules 1992, 25 (25), 6836-6841. https://doi.org/10.1021/ma00051a018.

(29) Kato, T.; Mizoshita, N.; Kishimoto, K. Functional Liquid-Crystalline Assemblies: SelfOrganized Soft Materials. Angew. Chem. Int. Ed. 2006, 45 (1), 38-68. https://doi.org/10.1002/anie.200501384.

(30) Yang, W.; Hutchinson, R. A. The Influence of Adding Functionality to Dispersant and Particle Core Compositions in Non-Aqueous Dispersion Polymerization. React. Funct. Polym. 2017, 114, 31-37. https://doi.org/10.1016/j.reactfunctpolym.2017.01.005. 
(31) Leibler, L. Thermodynamique Des Mélanges de Polymères (Aspect Théorique-Diagramme de Phase). In Initiation à la Chimie et la Physico-Chimie Macromoléculaires. Mélanges de Polymères; Cahier du GFP; Commission enseignement du GFP, 1985; Vol. 6.

(32) Excoffon, P.; Marechal, Y. Infrared Spectra of H-Bonded Systems: Saturated Carboxylic Acid Dimers. Spectrochim. Acta Part Mol. Spectrosc. 1972, 28 (2), 269-283. https://doi.org/10.1016/0584-8539(72)80251-4.

(33) Chu, L.-Y.; Li, Y.; Zhu, J.-H.; Chen, W.-M. Negatively Thermoresponsive Membranes with Functional Gates Driven by Zipper-Type Hydrogen-Bonding Interactions. Angew. Chem. Int. Ed. 2005, 44 (14), 2124-2127. https://doi.org/10.1002/anie.200462687.

(34) Deng, L.; Wang, C.; Li, Z.-C.; Liang, D. Re-Examination of the "Zipper Effect" in Hydrogen-Bonding Complexes. Macromolecules 2010, 43 (6), 3004-3010. https://doi.org/10.1021/ma902601d.

(35) Liu, Z.; Guo, Y.; Inomata, K. Lower Critical Solution Temperature Behavior of Poly(2Chloroethyl Vinyl Ether-Alt-Maleic Anhydride) in Organic Media. Polym. J. 2010, 42 (11), 901-904. https://doi.org/10.1038/pj.2010.84.

(36) Liu, Z.; Guo, Y.; Inomata, K. LCST-Type Phase Behavior of Poly(2-Chloroethyl Vinyl Ether-Alt-Maleic Anhydride) in n-Butyl Acetate. Polym. J. 2011, 43 (8), 676-682. https://doi.org/10.1038/pj.2011.41.

(37) Liu, Z.; Guo, Y.; Inomata, K. Reversible Thermoresponsive Behavior of Poly(2Chloroethyl Vinyl Ether-Alt-Maleic Anhydride) in Mixed Solvent of Tetrahydrofuran/Hexane. Colloid Polym. Sci. 2011, 289 (7), 791-798. https://doi.org/10.1007/s00396-011-2395-y. 


\title{
Supporting information
}

\section{Polymethacrylic Acid Shows Thermoresponsivity in an Organic Solvent}

\author{
Esther Cazares-Cortes, ${ }^{\mathrm{a}}$ Benjamin Baker, ${ }^{\mathrm{a}} \uparrow$ Kana Nishimori, ${ }^{\mathrm{b}}$ Makoto Ouchi, ${ }^{\mathrm{b}}$ and François \\ Tournilhac. $^{\text {a* }}$
}

${ }^{a}$ Molecular, Macromolecular Chemistry and Materials Laboratory, CNRS, ESPCI-Paris, PSL Research University, 10 rue Vauquelin 75005 Paris, France

${ }^{\mathrm{b}}$ Department of Polymer Chemistry, Graduate School of Engineering, Kyoto University, Katsura Nishikyo-ku, Kyoto 615-8510, Japan

Figure S1. Synthetic scheme of homopolymers a) pMAA and b) pHEA by RAFT...............................2

Figure S2. ${ }^{1} \mathrm{H}$ NMR spectrum of poly(2-hydroxyethyl acrylate) (pHEA) in DMSO- $d_{6} \ldots \ldots \ldots \ldots \ldots \ldots . . . . . . . . . . .3$

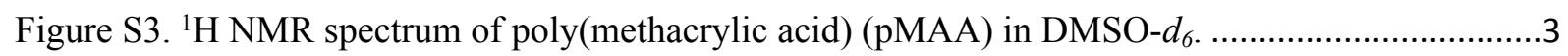

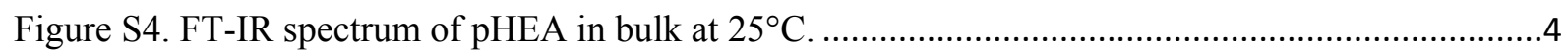

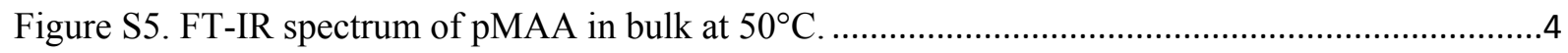

Figure S6. Synthesis of p(tBuMA) by Ru-catalyzed ATRP, time-conversion and SEC plots ................5

Figure S7. SEC curves of $\mathrm{p}(\mathrm{tBuMA})$ after purification by preparative SEC ........................................5

Figure S8. ${ }^{1} \mathrm{H}$ NMR spectra of $\mathrm{p}(\mathrm{tBuMA})$ after purification in $\mathrm{CDCl}_{3}(\mathrm{DP}=55$ and $\mathrm{DP}=103) \ldots \ldots \ldots \ldots$

Figure S9. ${ }^{1} \mathrm{H}$ NMR spectra of pMAA after dialysis in DMSO-d $\mathrm{d}_{6}:(\mathrm{DP}=59$ and $\mathrm{DP}=105) \ldots \ldots \ldots \ldots \ldots . .7$

Figure S10. IR signals of oxidation products of DME and water dissolved in DME............................7

Figure S11. IR signals of ethyl acetate, 2-hydroxyethyl acetate and pHEA .......................................

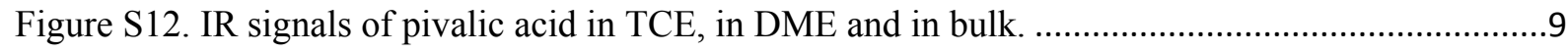

Figure S13. SANS data for pMAA and pHEA $\left(8 \mathrm{mg} \cdot \mathrm{mL}^{-1}\right.$ in DME- $\left.d_{10}\right)$ from 0 to $39^{\circ} \mathrm{C} \ldots \ldots \ldots \ldots \ldots \ldots . . . . . .10$

Figure S14. Projections of the solubility sphere of pMAA in 55 solvents …….................................10

Table S1. Solubility parameters of various solvents and solubility of pMAA therein ...........................11

Figure S15. Transmittance of pMAA $(\mathrm{n} \approx 18,59,105)$ in $\mathrm{DME}$ and $\mathrm{DME} / \mathrm{H}_{2} \mathrm{O}$ solutions .................12

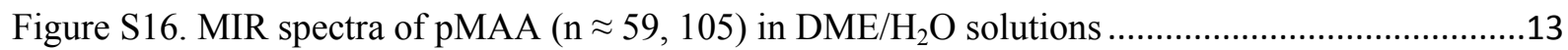


a)
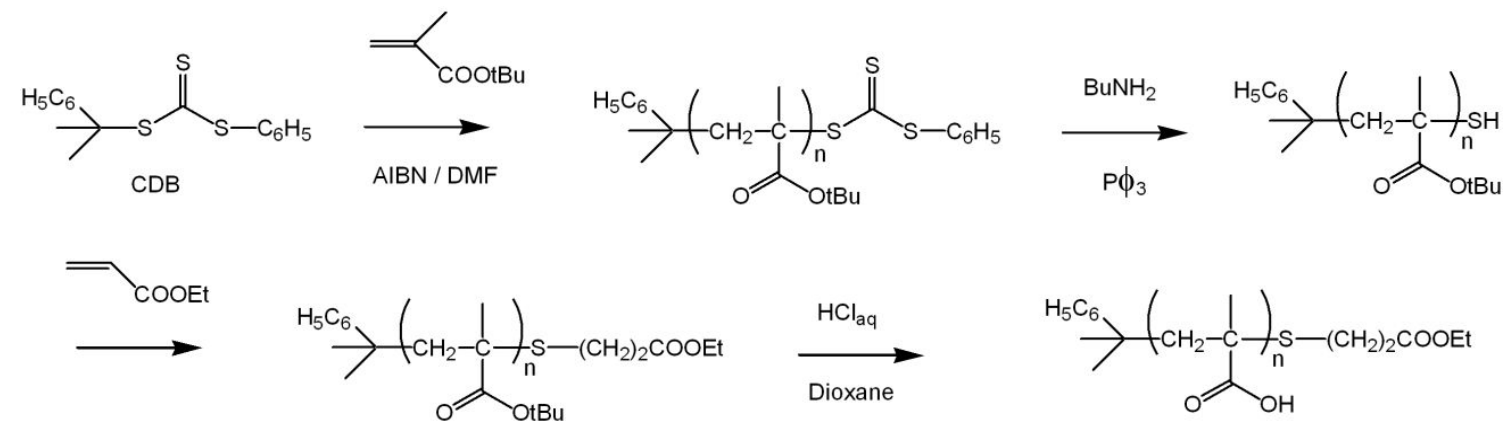

b)
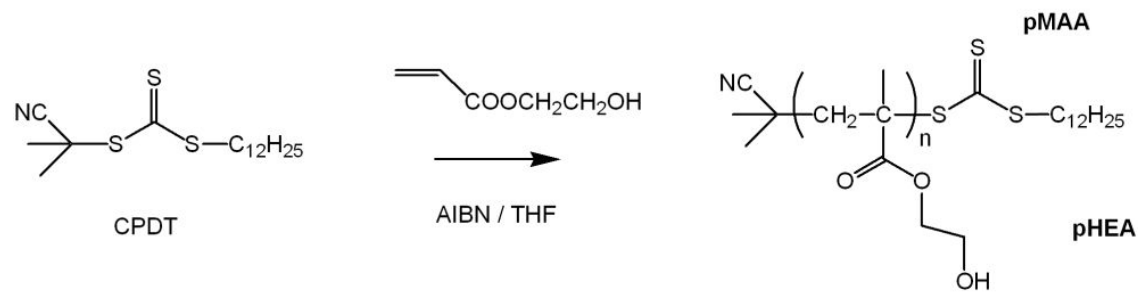

Figure S1. Synthetic scheme of homopolymers by RAFT a)poly(methacrylic acid) (pMAA) with tertbutyl methacrylate monomer at $65^{\circ} \mathrm{C}$ for 24 hours in DMF and b) poly(hydroxyl ethyl acrylate) (pHEA) with 2-hydroxyethyl acrylate monomer at $60^{\circ} \mathrm{C}, 2$ hours in DMF. 


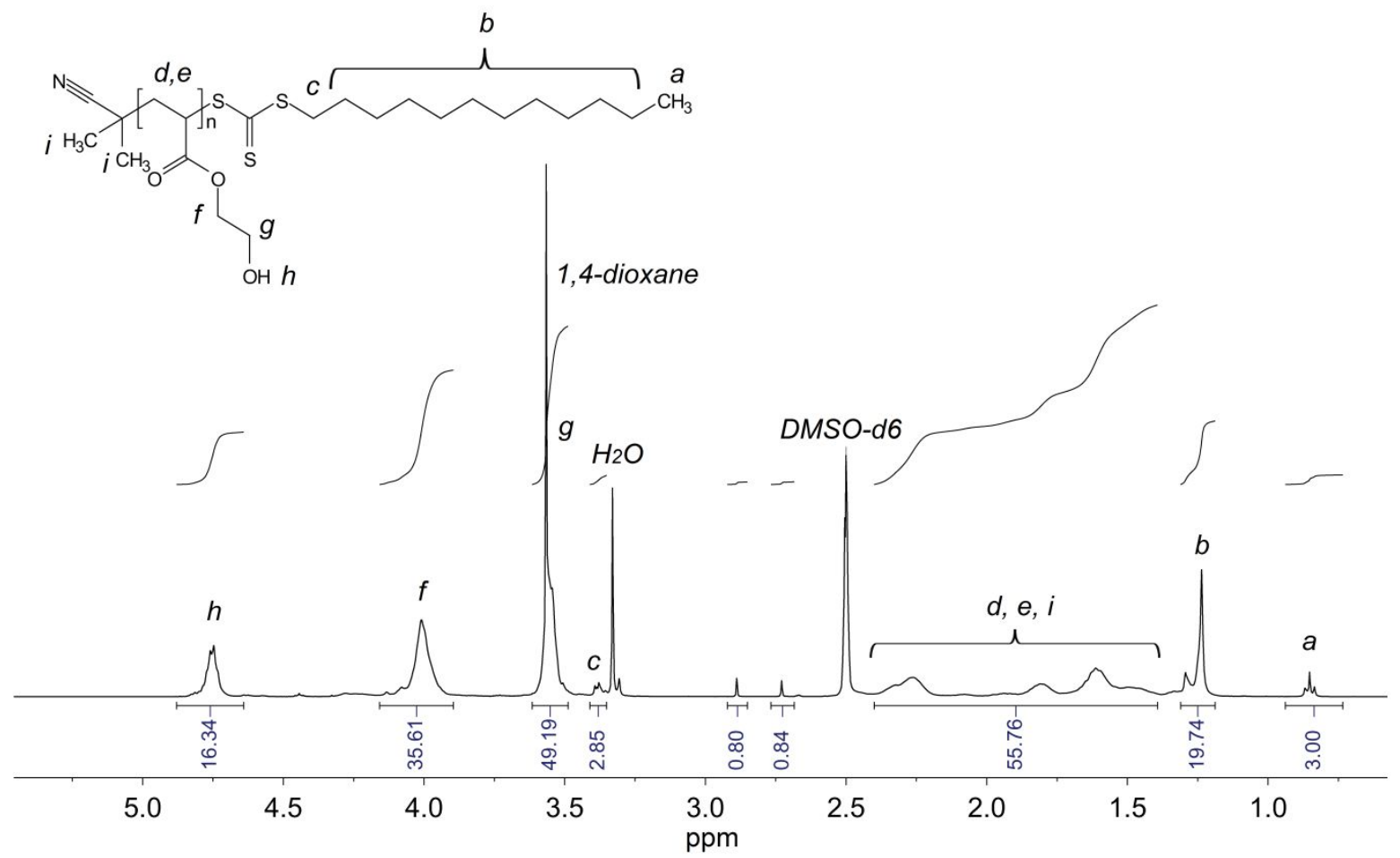

Figure S2. ${ }^{1} \mathrm{H}$ NMR spectrum of poly(2-hydroxyethyl acrylate) (pHEA) in DMSO- $d_{6}$.
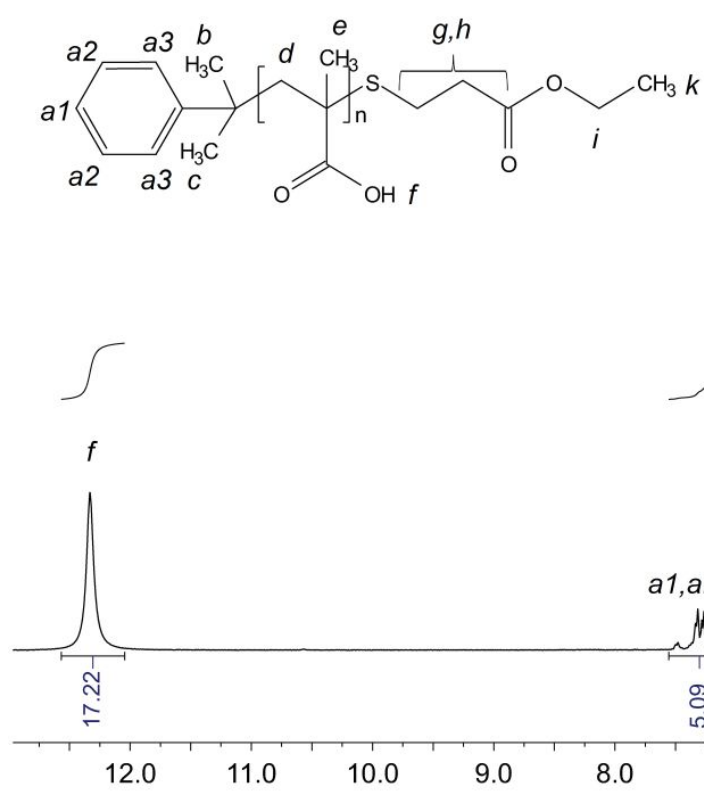<smiles>[Mg][Mg]</smiles>

Figure S3. ${ }^{1} \mathrm{H}$ NMR spectrum of poly(methacrylic acid) (pMAA) in DMSO- $d_{6}$. 


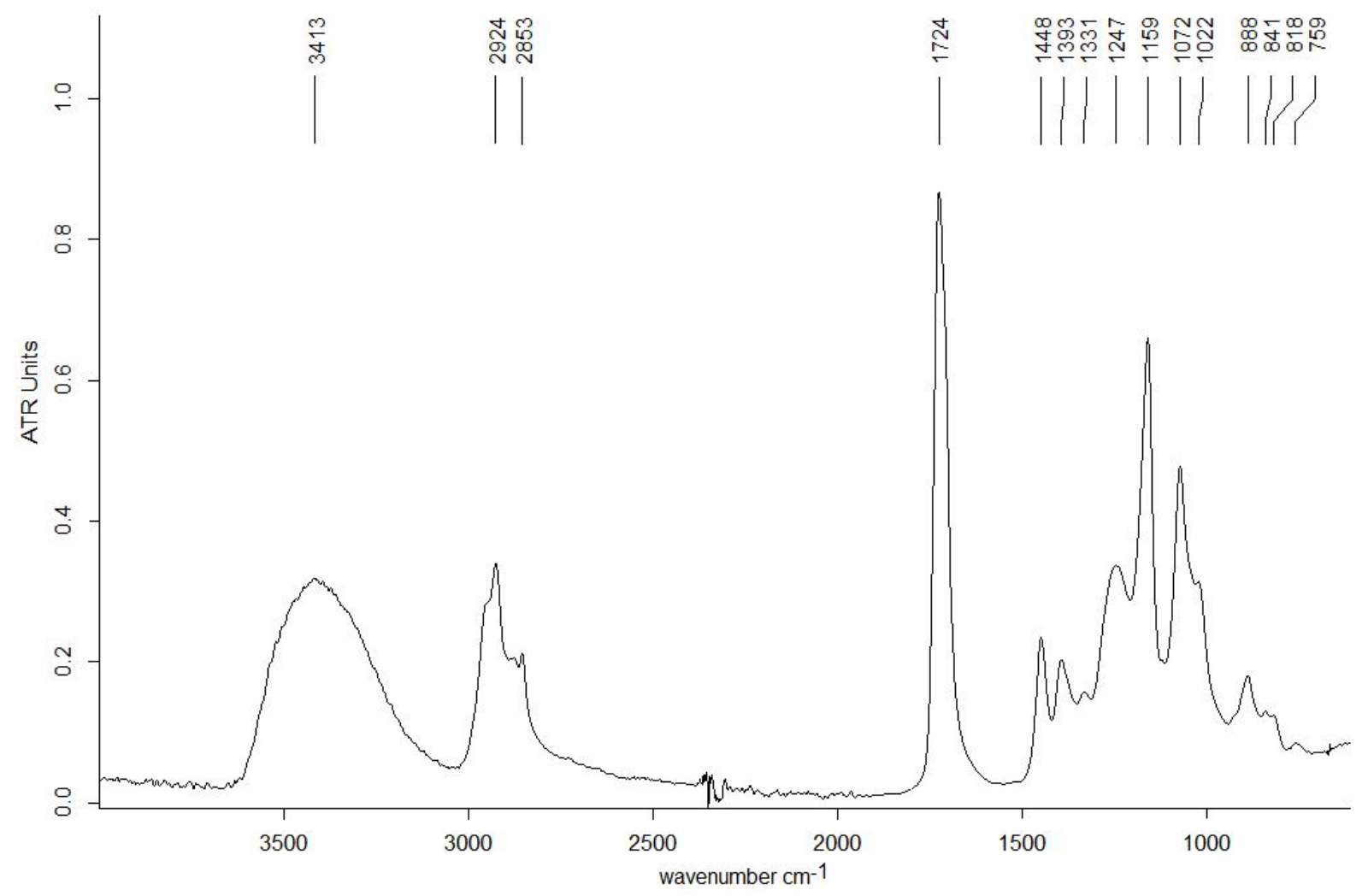

Figure S4. FT-IR spectrum of pHEA in bulk at $25^{\circ} \mathrm{C}$.

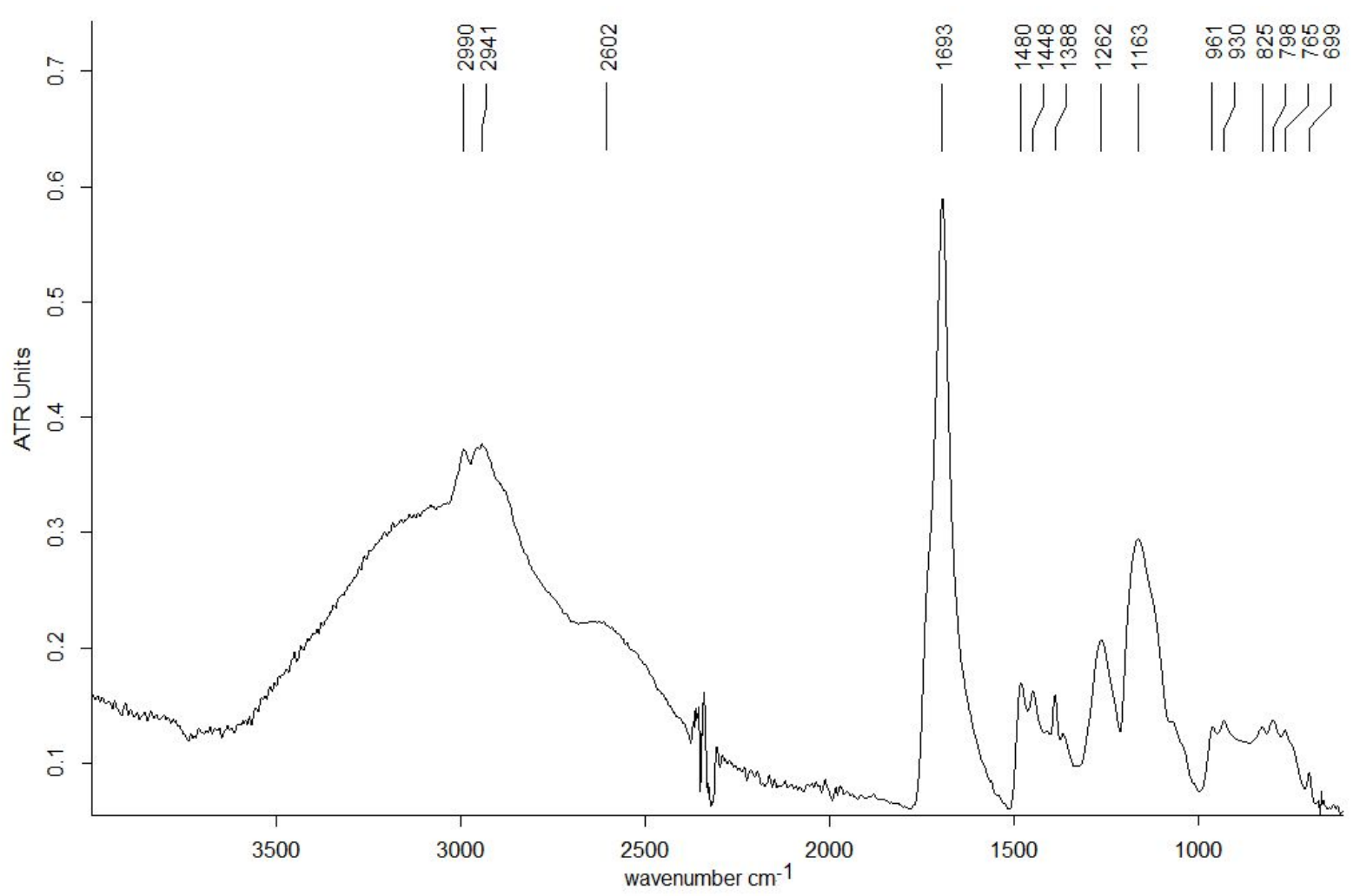

Figure S5. FT-IR spectrum of pMAA in bulk at $50^{\circ} \mathrm{C}$. 
a<smiles>CCOC(=O)C(Cl)c1ccccc1</smiles>

ECPA

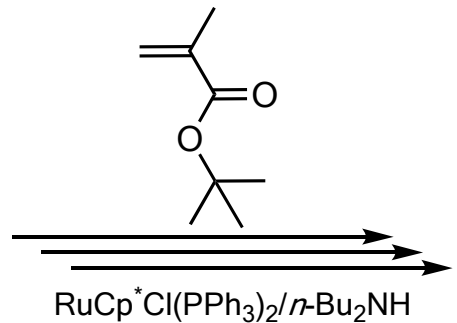

$\mathrm{RuCp}{ }^{*} \mathrm{Cl}\left(\mathrm{PPh}_{3}\right)_{2} / n-\mathrm{Bu}_{2} \mathrm{NH}$ b

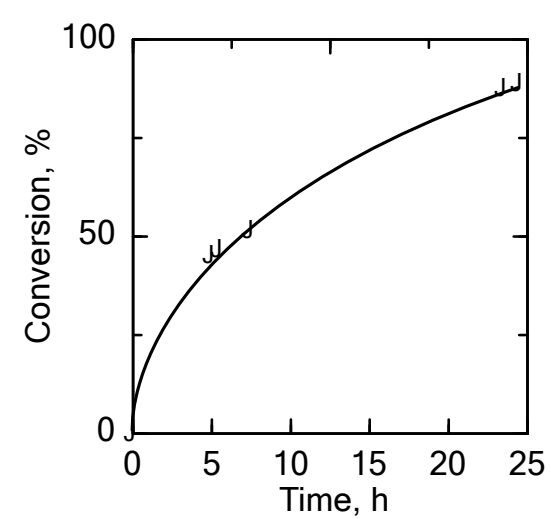<smiles>CCOC(=O)C(CCC(C)(C)C(=O)OC(C)(C)C)c1ccccc1</smiles>

$\mathrm{p}(\mathrm{tBuMA})$

C

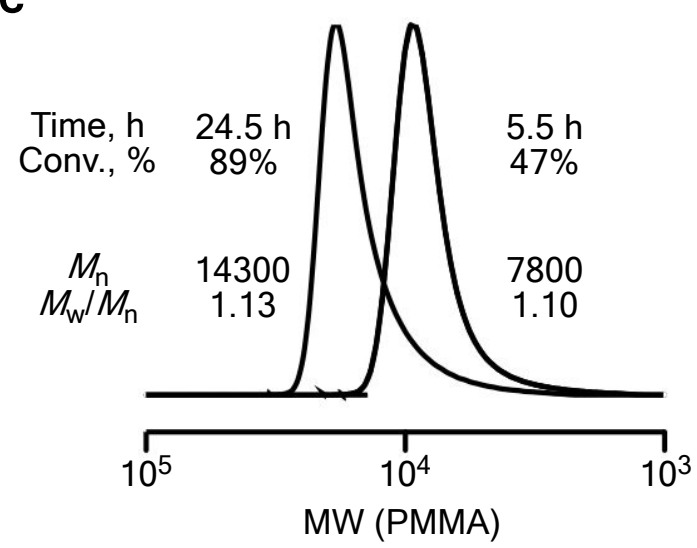

Figure S6. (a) Scheme of synthesis of $\mathrm{p}(\mathrm{tBuMA})$ by Ru-catalyzed ATRP, (b) time- conversion plots and (c) SEC curves of the p(tBuMA): $[\mathrm{tBuMA}]_{0} /[\mathrm{ECPA}]_{0} /\left[\mathrm{RuCp}{ }^{*} \mathrm{Cl}\left(\mathrm{PPh}_{3}\right)_{2}\right]_{0} /\left[n-\mathrm{Bu} \mathrm{H}_{2} \mathrm{NH}\right]_{0}=$ $4000 / 40 / 4 / 40 \mathrm{mM}$ in toluene at $80{ }^{\circ} \mathrm{C}$.

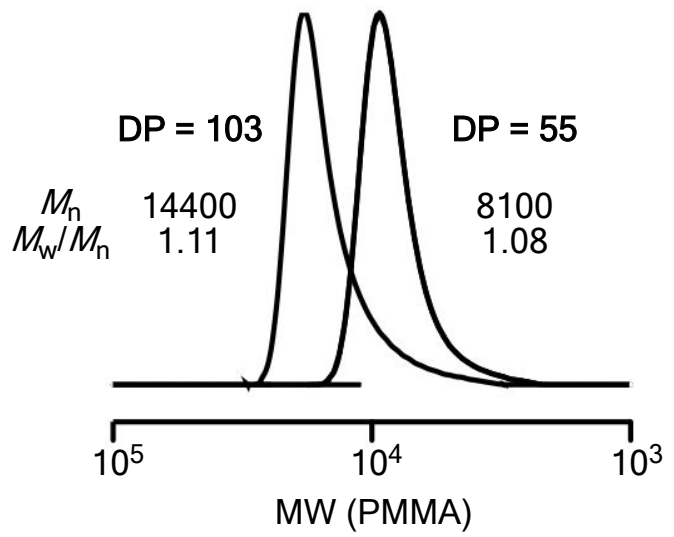

Figure S7. SEC curves of $\mathrm{p}(\mathrm{tBuMA})$ after purification by preparative SEC. 


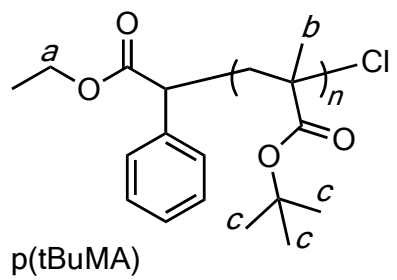

a

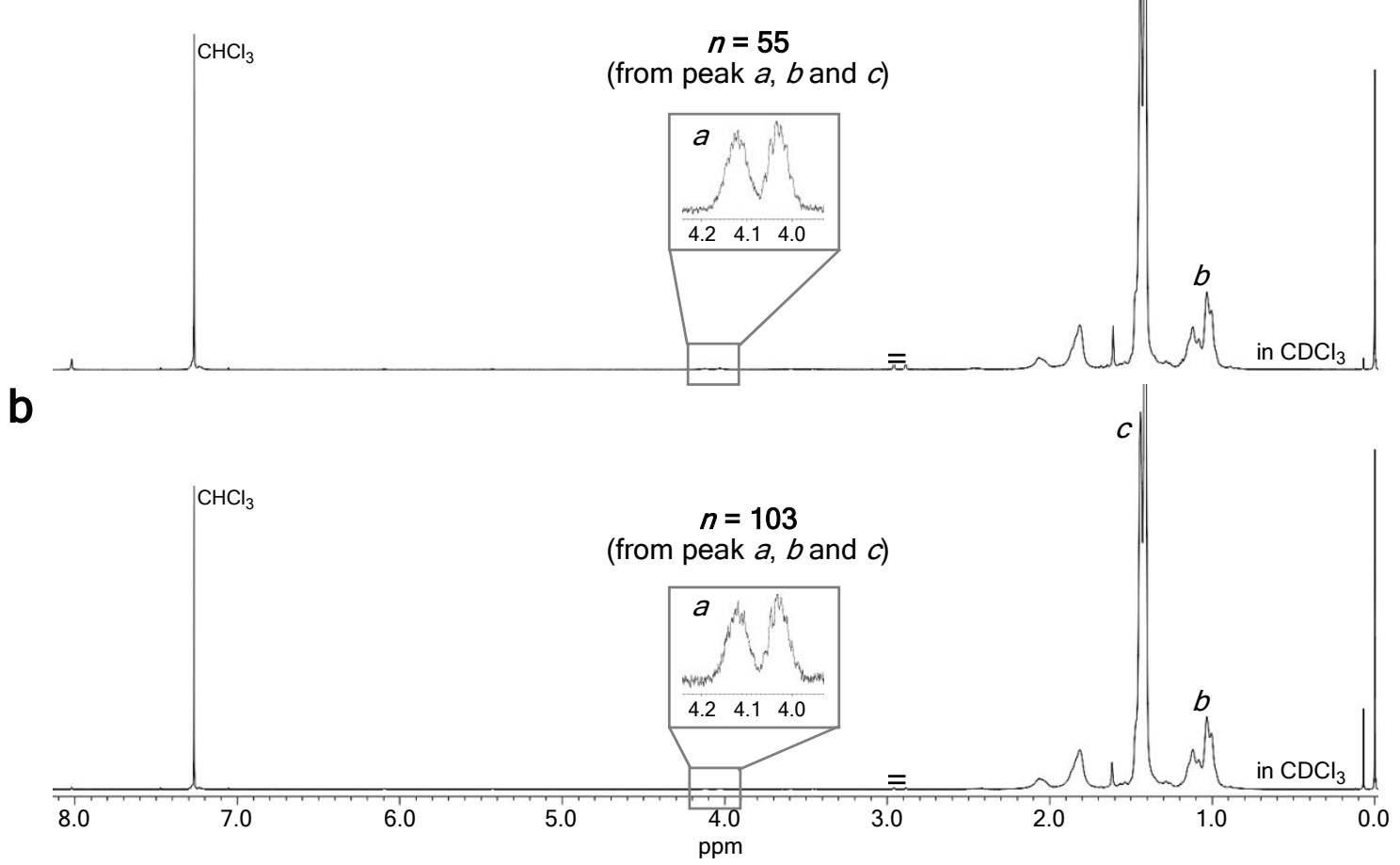

Figure S8. ${ }^{1} \mathrm{H}$ NMR spectra of $\mathrm{p}(\mathrm{tBuMA})$ after purification in $\mathrm{CDCl}_{3}:$ (a) $\mathrm{DP}=55$ and (b) $\mathrm{DP}=103$. 
a<smiles>CCOC(=O)C(CCC(=O)C(O)(Cl)Cl)c1ccccc1</smiles>

$$
n=59
$$

(from peak $a, b$ and $c$ )

b
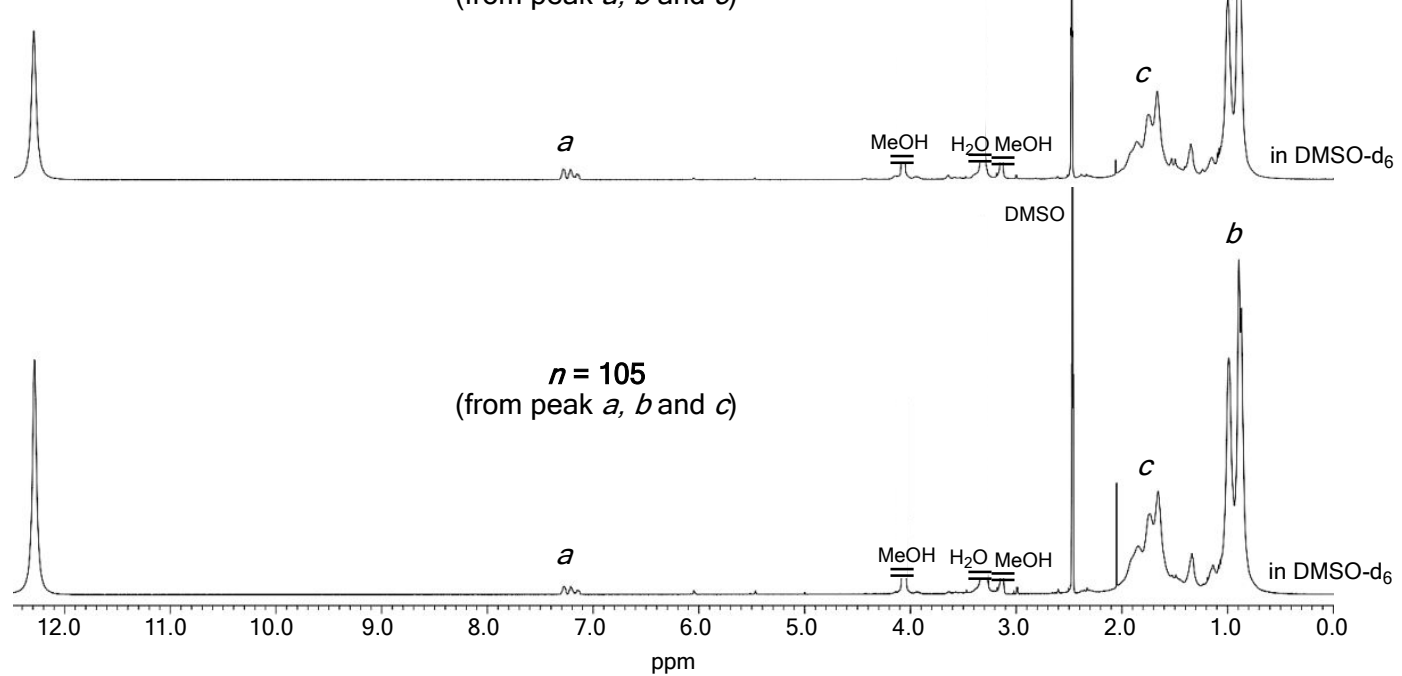

Figure S9. ${ }^{1} \mathrm{H}$ NMR spectra of pMAA after dialysis in DMSO-d 6 : (a) DP $=59$ and (b) DP $=105$.

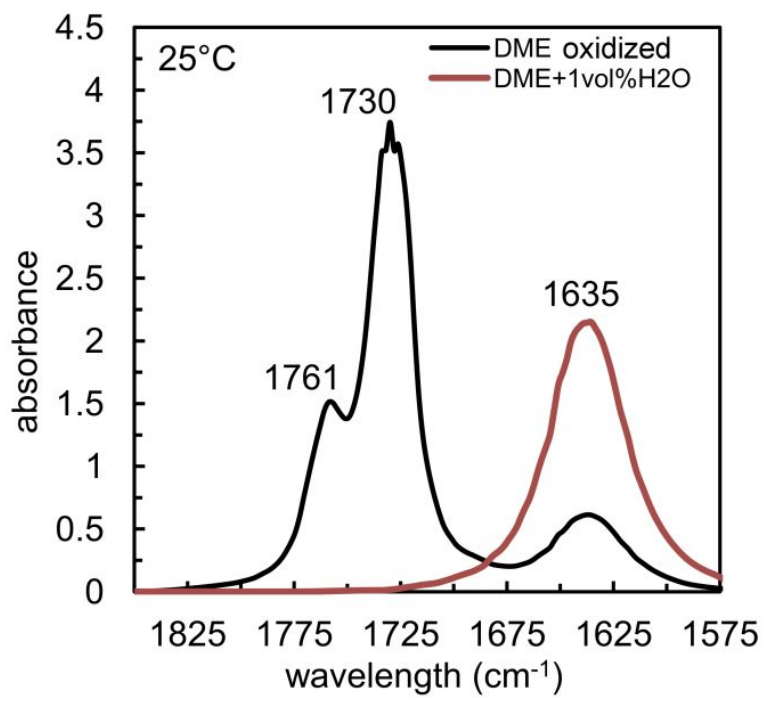

Figure S10. Black: Oxidation products in a batch of DME that has been in contact with air. Red: peak of water dissolved in DME. 

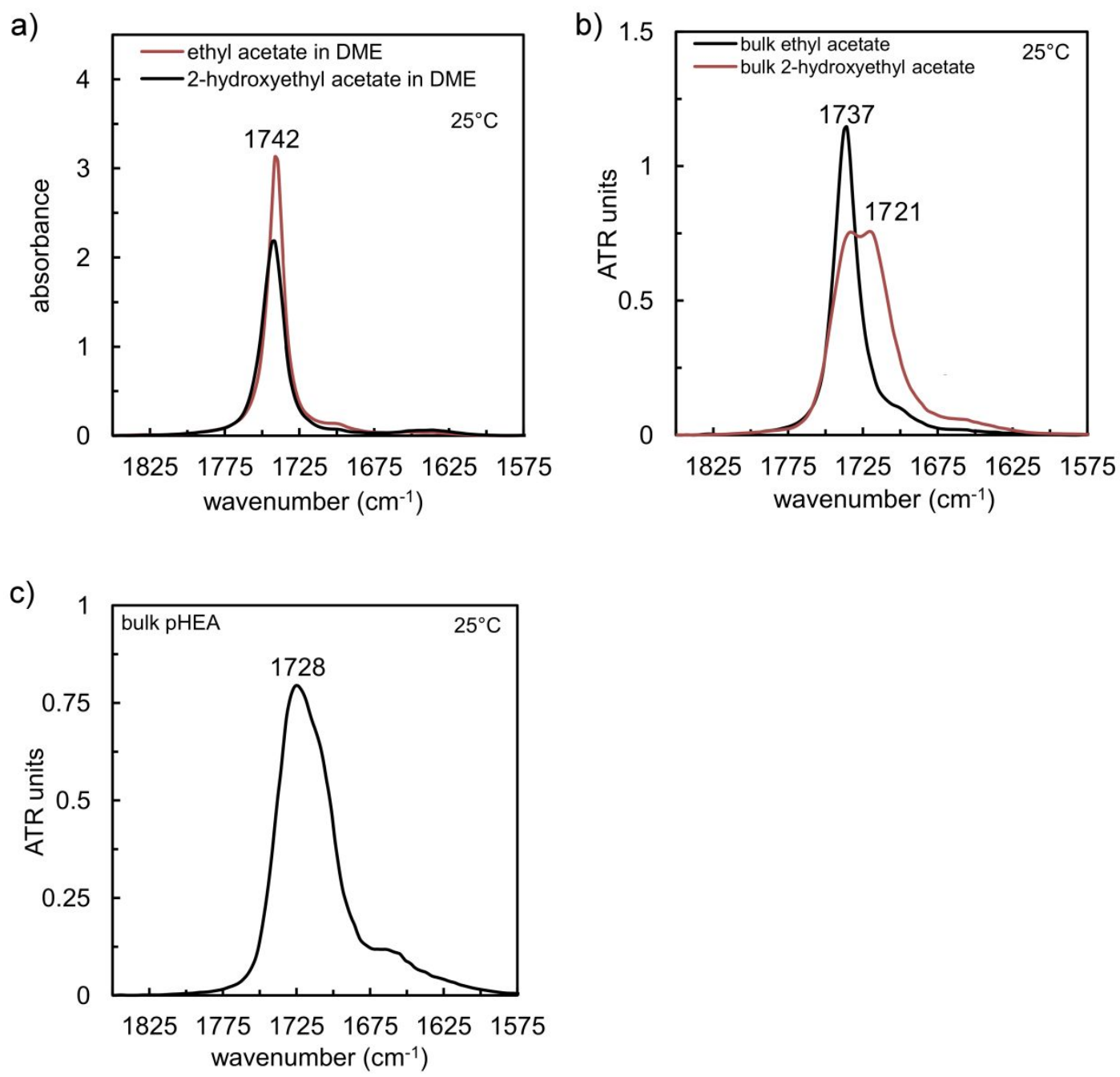

Figure S11. Magnification in the $\mathrm{C}=\mathrm{O}$ stretching region of a) $\mathrm{IR}$ absorption bands of ethyl acetate and 2-hydroxyethyl acetate in solution at $4 \mathrm{mg} / \mathrm{mL}$ in DME, b) IR ATR bands of ethyl acetate and 2hydroxyethyl acetate in bulk, c) IR ATR bands of pHEA in bulk. 


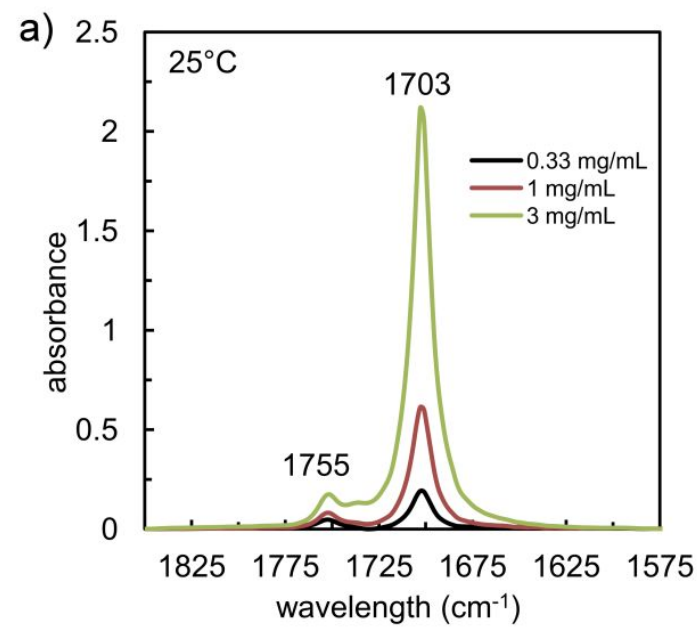

\begin{tabular}{cc} 
concentration & $\mathrm{A}_{1755} / \mathrm{A}_{1703}$ \\
\hline $0.33 \mathrm{mg} / \mathrm{mL}$ & 0.214 \\
$1 \mathrm{mg} / \mathrm{mL}$ & 0.125 \\
$3 \mathrm{mg} / \mathrm{mL}$ & 0.078
\end{tabular}
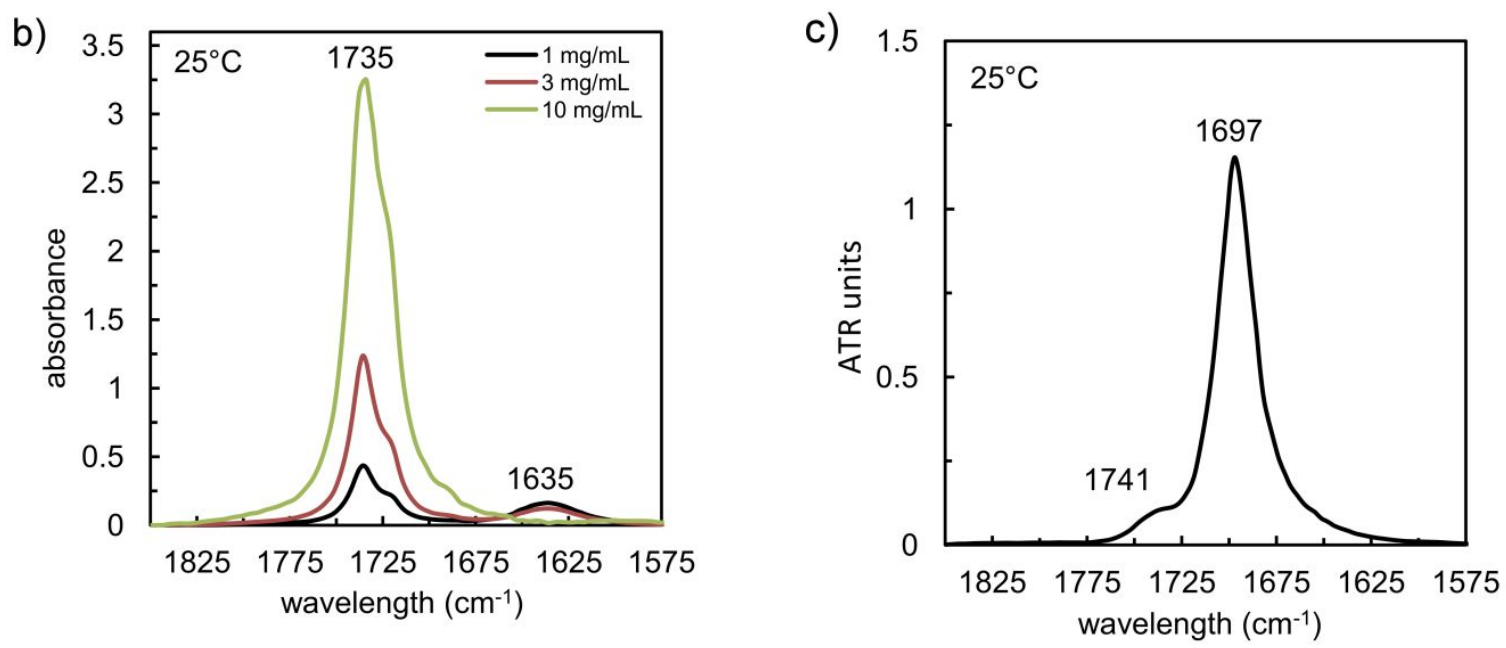

Figure S12. Magnification in the $\mathrm{C}=\mathrm{O}$ stretching region of a) $\mathrm{IR}$ absorption bands of pivalic acid in solution in TCE at different concentrations (table shows the ratio between absorbances measured at 1755 and $1703 \mathrm{~cm}^{-1}$ ), b) IR absorption bands of pivalic acid in solution in DME at different concentrations, c) IR ATR bands of pivalic acid in bulk.in Figure S12a. 
a)

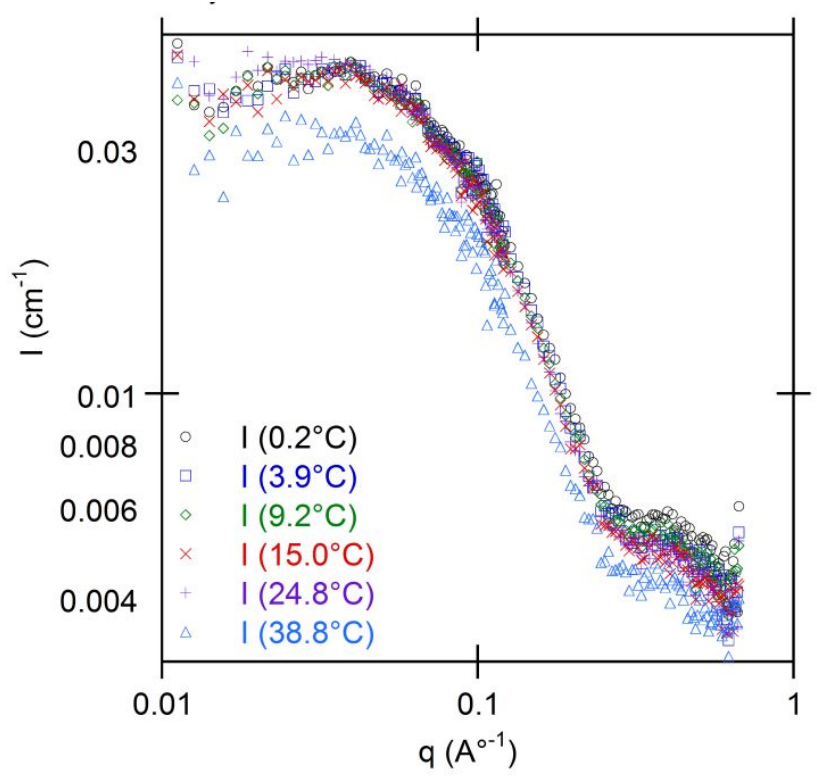

b)

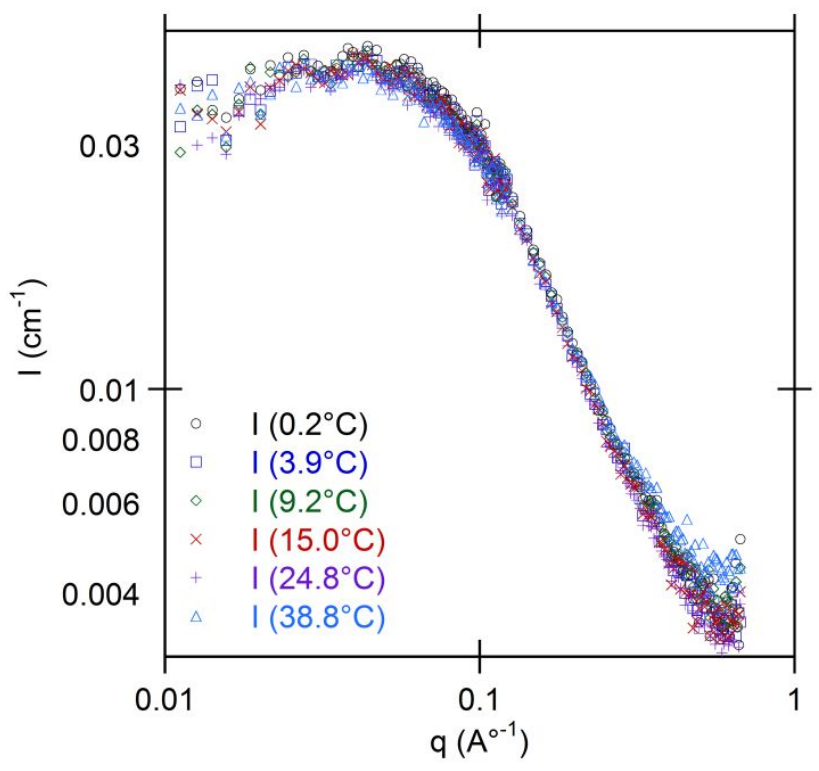

Figure S13. SANS data for a) pMAA and b) pHEA solutions in DME- $d_{10}\left(\right.$ at $8 \mathrm{mg} \cdot \mathrm{mL}^{-1}$ ) at temperatures from 0 to $39^{\circ} \mathrm{C}$.

a)

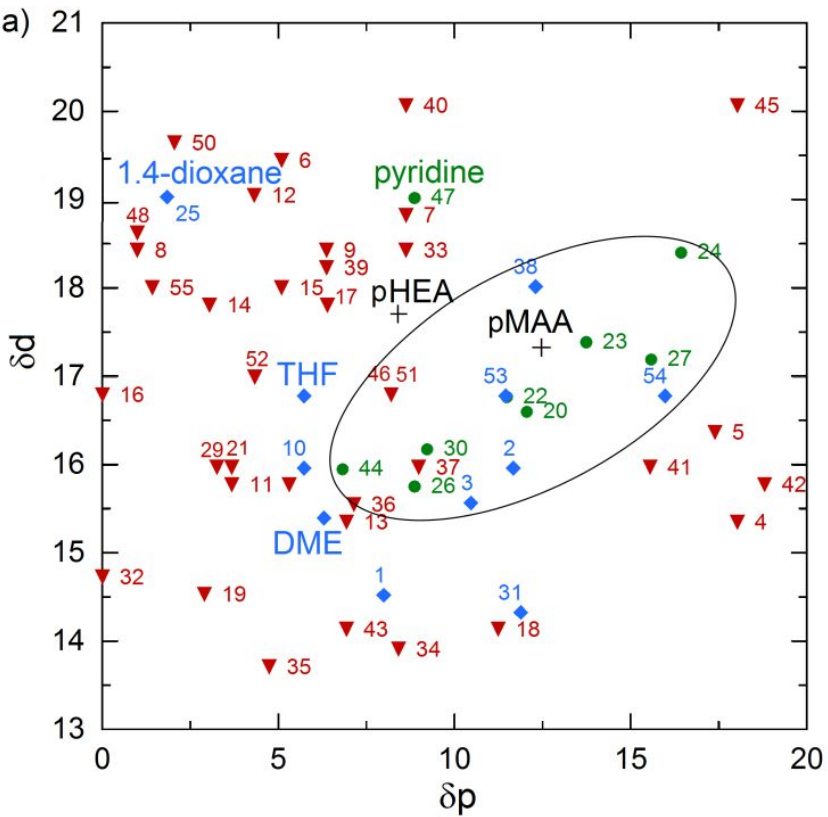

b)

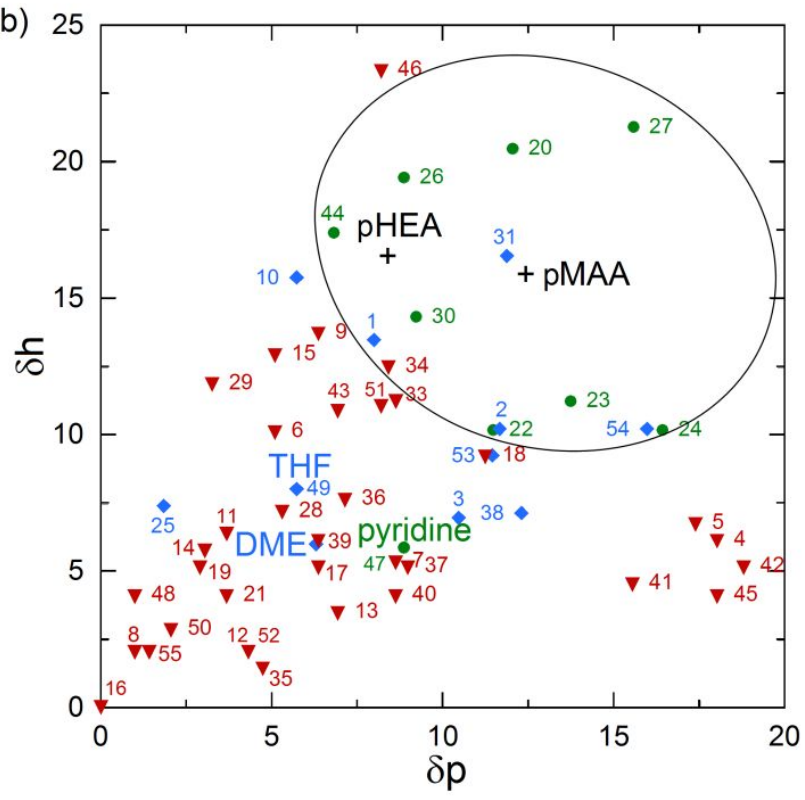

Figure S14. Projections of the solubility sphere of pMAA in 55 solvents (green: good solvent or good swelling agent; blue: poor swelling agent and red: non solvent) and the solubility region of pMAA in the a) $\delta_{d}-\delta_{p}$ and b) $\delta_{h^{-}} \delta_{p}$ plane based on the results of Table S1 ${ }^{1}$.Solvents such as, 1,4-dioxane, tetrahydrofurane (THF), 1.2-dimethoxyethane (DME) and pyridine, although located outside the Hansen solubility sphere are capable of solubilising pMAA and pHEA at $8 \mathrm{mg} . \mathrm{mL}$, thanks to the formation of specific hydrogen bonds between the polymer chains and the solvent. 
Table S1. Solubility parameters of various solvents and extent of solubility of pMAA in this liquids : good solvent (1), good swelling agent (2), poor swelling(3) and nonsolvent (4). Values reproduced from $^{1}$ (except for DME values obtained from ${ }^{2}$ ).

\begin{tabular}{|c|c|c|c|c|c|c|}
\hline No. & Solvent & $\delta_{d, s}$ & $\delta_{p, s}$ & $\delta_{h, s}$ & $\delta_{t, s}$ & Quality \\
\hline 1 & Acetic acid & 14.53 & 7.983 & 13.51 & 21.49 & 3 \\
\hline 2 & Acetic anhydride & 15.97 & 11.67 & 10.24 & 22.31 & 3 \\
\hline 3 & Acetone & 15.56 & 10.44 & 6.96 & 20.06 & 3 \\
\hline 4 & Acetonitrile & 15.35 & 18.01 & 6.14 & 24.36 & 4 \\
\hline 5 & Acrylonitrile & 16.38 & 17.40 & 6.75 & 24.77 & 4 \\
\hline 6 & Aniline & 19.45 & 5.12 & 10.03 & 22.52 & 4 \\
\hline 7 & Benzaldehyde & 18.83 & 8.60 & 5.32 & 21.29 & 4 \\
\hline 8 & Benzene & 18.42 & 1.02 & 2.05 & 18.42 & 4 \\
\hline 9 & Benzyl alcohol & 18.42 & 6.35 & 13.71 & 23.95 & 4 \\
\hline 10 & 1-Butanol & 15.97 & 5.73 & 15.76 & 23.13 & 3 \\
\hline 11 & n-Butyl acetate & 15.77 & 3.68 & 6.35 & 17.40 & 4 \\
\hline 12 & Chlorobenzene & 19.04 & 4.30 & 2.047 & 19.65 & 4 \\
\hline 13 & 1 Chlorobutane & 15.35 & 6.96 & 3.48 & 17.19 & 4 \\
\hline 14 & Chloroform & 17.81 & 3.07 & 5.73 & 19.04 & 4 \\
\hline 15 & rn-Cresol & 18.01 & 5.12 & 12.90 & 22.72 & 4 \\
\hline 16 & Cyclohexane & 16.79 & 0 & 0 & 16.79 & 4 \\
\hline 17 & Cyclohexanone & 17.81 & 6.35 & 5.12 & 19.65 & 4 \\
\hline 18 & 1,2-Dichloroethane & 14.12 & 11.26 & 9.21 & 19.65 & 4 \\
\hline 19 & Diethyl ether & 14.53 & 2.87 & 5.12 & 15.76 & 4 \\
\hline 20 & Diethlene glycol & 16.60 & 12.00 & 20.47 & 29.89 & 1 \\
\hline 21 & Diisobutyl ketone & 15.97 & 3.68 & 4.09 & 16.99 & 4 \\
\hline 22 & N,N-dimethyl acetamide & 16.79 & 11.46 & 10.24 & 22.72 & 2 \\
\hline 23 & $\mathrm{~N}, \mathrm{~N}$-dimethyl formamide & 17.40 & 13.72 & 11.26 & 24.77 & 2 \\
\hline 24 & Dimethyl sulfoxide & 18.42 & 16.38 & 10.24 & 26.61 & 1 \\
\hline 25 & 1,4-Dioxane & 19.04 & 1.84 & 7.37 & 20.47 & 3 \\
\hline 26 & Ethanol & 15.76 & 8.80 & 19.45 & 26.61 & 1 \\
\hline 27 & Ethanol amine & 17.19 & 15.56 & 21.29 & 31.52 & 2 \\
\hline 28 & Ethyl acetate & 15.76 & 5.32 & 7.164 & 18.01 & 4 \\
\hline 29 & 2-Ethyl hexanol & 15.97 & 3.28 & 11.87 & 20.27 & 4 \\
\hline 30 & Ethyl cellosolve & 16.17 & 9.21 & 14.33 & 23.54 & 2 \\
\hline 31 & Formic acid & 14.33 & 11.87 & 16.58 & 24.97 & 3 \\
\hline 32 & n-Heptane & 14.74 & 0 & 0 & 14.74 & 4 \\
\hline 33 & n-Hexamethyl phosphoramide & 18.42 & 8.60 & 11.26 & 23.13 & 4 \\
\hline 34 & Isoamyl alcohol & 13.92 & 8.39 & 12.49 & 20.47 & 4 \\
\hline 35 & Isopropyl ether & 13.72 & 4.71 & 1.43 & 14.33 & 4 \\
\hline 36 & Methyl acetate & 15.56 & 7.16 & 7.57 & 18.63 & 4 \\
\hline
\end{tabular}




\begin{tabular}{|c|c|c|c|c|c|c|}
\hline 37 & Methyl ethyl ketone & 15.97 & 9.01 & 5.12 & 19.04 & 4 \\
\hline 38 & N-methyl-2-pyrolidone & 18.01 & 12.28 & 7.16 & 22.93 & 3 \\
\hline 39 & Methylene chloride & 18.22 & 6.35 & 6.14 & 20.27 & 4 \\
\hline 40 & Nitrobenzene & 20.06 & 8.60 & 4.10 & 22.31 & 4 \\
\hline 41 & Nitroethane & 15.97 & 15.56 & 4.50 & 22.72 & 4 \\
\hline 42 & Nitromethane & 15.76 & 18.83 & 5.12 & 24.56 & 4 \\
\hline 43 & n-Octyl alcohol & 14.12 & 6.96 & 10.85 & 19.04 & 4 \\
\hline 44 & 1-Propanol & 15.97 & 6.76 & 17.40 & 24.56 & 2 \\
\hline 45 & Propylene carbonate & 20.06 & 18.01 & 4.09 & 27.22 & 4 \\
\hline 46 & Propylene glycol & 16.79 & 8.19 & 23.34 & 30.30 & 4 \\
\hline 47 & Pyridine & 19.04 & 8.80 & 5.94 & 21.90 & 2 \\
\hline 48 & Styrene & 18.63 & 1.02 & 4.09 & 19.04 & 4 \\
\hline 49 & Tetrahydrofuran & 16.79 & 5.73 & 7.98 & 19.45 & 3 \\
\hline 50 & Tetralin & 19.65 & 2.05 & 2.87 & 20.06 & 4 \\
\hline 51 & Tetramethylurea & 16.79 & 8.19 & 11.05 & 21.70 & 4 \\
\hline 52 & 1,1,1-Trichloroethane & 16.99 & 4.30 & 2.05 & 17.81 & 4 \\
\hline 53 & Triethyl phosphate & 16.79 & 11.46 & 9.21 & 22.31 & 3 \\
\hline 54 & Trimethyl phosphate & 16.79 & 15.97 & 10.24 & 25.38 & 3 \\
\hline 55 & Toluene & 18.01 & 1.43 & 2.05 & 18.63 & 4 \\
\hline DME & 1.2-dimethoxyethane & 15.40 & 6.30 & 6.00 & 17.70 & 3 \\
\hline
\end{tabular}

\section{References to Table S1}

(1) Ho, B.-C.; Chin, W.-K.; Lee, Y.-D. Solubility Parameters of Polymethacrylonitrile, Poly(Methacrylic Acid) and Methacrylonitrile/Methacrylic Acid Copolymer. J. Appl. Polym. Sci. 42 (1), 99-106. https://doi.org/10.1002/app.1991.070420112.

(2) Hansen, C. M. Hansen Solubility Parameters : A User's Handbook; CRC Press, 2000.

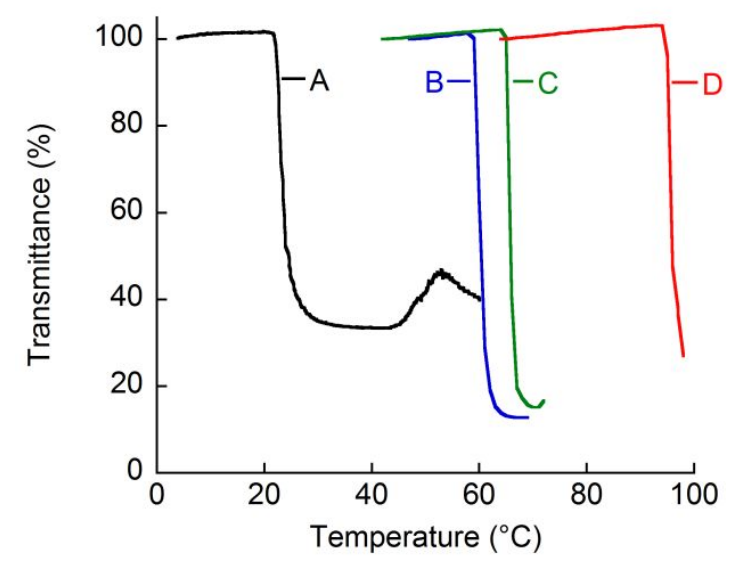

Figure S15. Transmittance at $670 \mathrm{~nm}$ through a pathlength of $1 \mathrm{~cm}$ of A: pMAA $(\mathrm{n} \approx 18)$ in DME, B: pMAA $(\mathrm{n} \approx 59)$ in DME +3 vol $\% \mathrm{H}_{2} \mathrm{O}, \mathrm{C}: \mathrm{pMAA}(\mathrm{n} \approx 105)$ in DME +6 vol $\% \mathrm{H}_{2} \mathrm{O}$ and D: pMAA ( $\approx 59$ ) in $\mathrm{DME}+6 \mathrm{vol} \% \mathrm{H}_{2} \mathrm{O}$ solutions at $8 \mathrm{mg} \cdot \mathrm{mL}^{-1}$ as a function of temperature (heating rate: $\left.1^{\circ} \mathrm{C} \cdot \mathrm{min}^{-1}\right)$ 

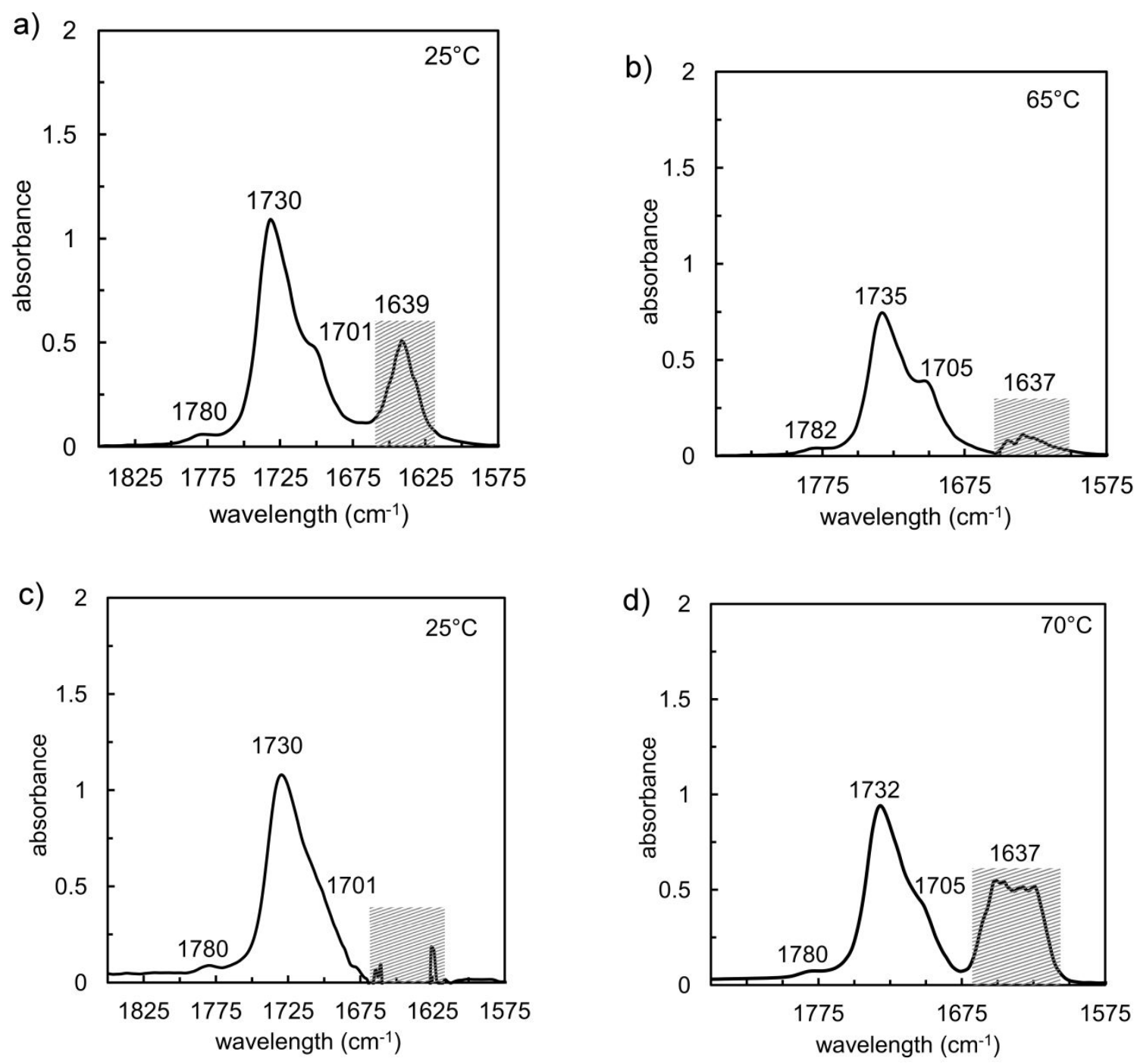

Figure S16. MIR spectra of pMAA $(n \approx 59)$ in DME +3 vol $\% \mathrm{H}_{2} \mathrm{O}$ solutions at a) $25^{\circ} \mathrm{C}$ and b) $65^{\circ} \mathrm{C}$; and pMAA $(n \approx 105)$ in DME +6 vol $\% \mathrm{H}_{2} \mathrm{O}$ solutions at $\left.\mathrm{c}\right) 25^{\circ} \mathrm{C}$ and d) $70^{\circ} \mathrm{C}$. Concentration $=8$ $\left.\mathrm{mg} \cdot \mathrm{mL}^{-1}\right)$. The hatched area corresponds to saturation due to water absorption. 